\title{
ÖZGÜRSÜZLÜK, KANUN VE BİREYSEL BAŞVURU: TÜRK BİREYSEL BAŞVURU SİSTEMİNE BİR ELEŞTİRİ
}

\author{
UNFREEDOM, STATUTE AND INDIVIDUAL APPLICATION: \\ A CRITIQUE OF THE TURKISH INDIVIDUAL APPLICATION SYSTEM
}

\author{
Yahya Berkol GÜLGEÇ*
}

Makale Bilgi

Gönderi: 18/12/2020

Kabul : 14/10/2021

Anahtar Kelimeler

Bireysel Başvuru, Kanun,

Özgürsüzlük,

Negatif Özgürlük,

Temel Hak ve

Hürriyetler.

\section{Article Info}

Received: 18/12/2020

Accepted: 14/10/2021

Keywords

Individual Application, Statute,

Unfreedom,

Negative Freedom,

Fundamental Rights and Freedoms.
Özet

https://dai.org/l1.21492/inuhfd.842645 do

Türk bireysel başvuru sistemi ilk andan itibaren pek çok eleştiriye konu olmuştur. Makale Türk bireysel başvuru sistemini yalnızca kanunlardan kaynaklı temel hak ve özgürlük ihlalleri açısından eleştirmektedir. Buna göre, doğrudan kanundan kaynaklı ihlaller dolayısıyla bireysel başvuru yapılamaması ve temel hak ihlaline yol açan kanunun bireysel başvuru neticesinde iptal edilememesi sistem açısından önemli bir eksikliktir. Bunun nedeni temel hak ve özgürlük ihlaline yol açan kanun geçersiz kılınmadıkça ihlalin devam etmesi ve hakların etkili korumadan mahrum kalmasıdır. Türk bireysel başvuru sistemi kapsamındaysa hak ihlalinin yalnızca birel bir normun muhataba uygulanmasıyla gerçekleşeceği düşünülmekte gibidir. $\mathrm{Bu}$ yanılgının neticesinde telafisi güç bir tuhaflık ortaya çıkmaktadır. Buna göre, bireysel başvuruda bir hukuk sisteminin kendilerinden beklediğini yapıp geçerli bir kanuna uygun davranan kimselerin hakların ihlal edildiği, kanunu ihlal eden kişilerinse Anayasa Mahkemesinin ihlal kararıyla ödüllendirildiği durumlara rastlamak mümkündür. Makalede pozitif hukuk çerçevesinde bu eksiklikleri gidermenin yolları irdelenmekte, bu yolların etkili birer çözüm olmaktan uzak olduğu vurgulanarak sorunun anayasa değişikliği ile çözülmesi önerilmektedir.

\begin{abstract}
The Turkish individual application system has been subjected to many criticisms from the first time on. The article criticizes the Turkish individual application system only with respect to violations stemming from statutes. Accordingly, the lack of individual application based on violations directly stemming from statutes and the fact that the violating statute cannot be annulled as a result of the individual application process are important deficiencies of the system. This is because unless the statute violating the fundamental rights and freedoms is annulled, the violation will persist and it will be impossible to protect rights effectively. The Turkish individual application system seems to suggest that the violation of the right occurs only when an individual norm addressing the person is applied. This leads to a peculiarity that is difficult to eliminate. Accordingly, one might come across cases where the rights of individuals acting as expected by the legal system by complying with a valid statute are violated whereas those violating the valid statute are rewarded by the violation verdict of the Constitutional Court. The article examines the ways to circumvent these deficiencies within the bounds of positive law, stresses that these ways are far from being efficient, and suggests the solution of the problem via constitutional revision.
\end{abstract}




\section{GİRIŞ}

5982 sayılı Anayasa Değișikliği Hakkında Kanun’un yürürlüğe girdiği 12 Eylül 2010 tarihinden bu yana Türk hukukunda bireysel başvuru sistemi, genel olarak olumlu bir gelişme olarak görülmekle birlikte, birçok eleştiriye konu olmuştur. Bireysel başvuru sistemine yönelik eleştiriler geniş bir yelpazeye yayılmıştır. Başlıca eleştiri konularını şu şekilde sıralıyoruz: 6216 sayılı Anayasa Mahkemesinin Kuruluşu ve Yargılama usulleri Hakkında Kanun'un (6216 sayılı Kanun) Anayasanın 148/3 maddesinde geçen "kamu gücü" kriterini anayasaya aykırı biçimde belli işlemlerle sınırlandırmas1 ${ }^{1}$, yine 6216 sayılı Kanun'un Anayasa'nın 148/3 maddesinin "herkes" ifadesini kamu tüzel kişilerini dışlayacak şekilde daraltmas ${ }^{2}$, korumanın Avrupa İnsan Hakları Sözleşmesi ve Protokolleri ile 1982 Anayasasında birlikte bulunan hak ve özgürlüklerle sınırlandırılması ${ }^{3}$, Anayasanın "olağan kanun yollarının" tüketilmesinden bahsetmesine rağmen 6216 sayılı Kanun'un "idari ve yargısal başvuru yolları" gibi daha geniş bir kapsamdan bahsetmesi ${ }^{4}$, Anayasa Mahkemesine ihlale yol açtığını tespit ettiği normu geçersiz kılma yetkisinin tanınmamas $1^{5}$.

$\mathrm{Bu}$ eleştirilerin neredeyse tamamına hak vermek gerekir. Bu eleştirilere rağmen Türk bireysel başvuru sisteminde gerekli değişiklikler yapılmamıştır. Bu çalışmada yalnızca kanunlara ilişkin düzenlemelerin bireysel başvuru ve genel olarak temel hak ve hürriyetlerin korunması açısından yol açtığı sorunlara değinmek istiyoruz. Bunun bir sebebi de makalenin bu konuda doktrine daha orijinal bir katkı sunacağını düşünmemizdir.

Bizim incelememizin yukarıda zikrettiğimiz başlıklardan ikisiyle ilişkili olduğunu söyleyebiliriz. İlk olarak Anayasa metninde geçen "kamu gücünden kaynaklanan ihlal" kriterinin 6216 sayılı Kanun tarafından anayasaya aykırı biçimde daraltılmasıyla bir ilişki kurulabilir. Doğrudan kanunlardan kaynaklanan ihlallerin bireysel başvuruya konu edilememesinin ardında pek çok sebep olabilir. Biz bu sebeplerin geçersiz olduğunu ve kanunların (esasında genel nitelikli bütün normların) bireysel başvuru kapsamı dışında bırakılmasının temel hak ve hürriyetlerin korunması açısından önemli bir kusur teşkil ettiği kanısındayız. Eleştirilerimiz ikinci olarak Anayasa Mahkemesine temel hak ve özgürlükleri ihlal eden bir normu iptal etme yetkisinin verilmemesiyle ilişkilidir. Çalışmamızda bu kusurların sakıncalarına dikkat çekip olası çözüm yollarına değineceğiz. Bunu yaparken temel hak ve özgürlüklerin ihlalinin ne zaman gerçekleştiğine ve Türk hukuk sisteminin konuya yaklaşımındaki bir "tuhaflığa" dikkat çekeceğiz.

Devam etmeden önce terminolojik bir hususun da altını çizelim. Söz konusu bireysel başvuru olunca hak, özgürlük, hürriyet, temel hak ve hürriyetler gibi terimlerin kullanımı sorunu karşımıza çıkmaktadır. Biz bu çalışmada özgürlük ve hürriyet kavramlarını eş anlamlı olarak kullanıyoruz. "Temel hak ve özgürlükler" ifadesini teknik olarak Anayasa tarafindan güvence altına alınmış hak veya hürriyetleri ifade etmek için kullanmamıza rağmen ${ }^{6}$, metin içinde herhangi

\footnotetext{
${ }^{1}$ Örn. bkz. ŞİRIN, Tolga: Anayasa Mahkemesi Kararları Işı̆̆ında Bireysel Başvuru Hakkı, On İki Levha, İstanbul 2015, s.85-87; ŞİRİN, Tolga: Türkiye'de Anayasa Şikâyeti (Bireysel Başvuru): İnsan Hakları Avrupa Mahkemesi ve Almanya Uygulamas1 ile Mukayeseli Bir İnceleme, On İki Levha, İstanbul 2013, s.279-284; AYDIN, Öykü Didem: "Türk Anayasa Yargısında Yeni Bir Mekanizma: Anayasa Mahkemesi'ne Bireysel Başvuru", Gazi Üniversitesi Hukuk Fakültesi Dergisi, 15(4), 2011, s.145-146; SAĞLAM, Fazıl: “Anayasa Şikâyetini Bekleyen Sorunlar”, in Anayasa Mahkemesine Bireysel Başvuru: Anayasa Şikayeti/Anlamı ve Olası Sorunlar, TBB Yayını, Ankara 2011, s.28; ŞAHBAZ, İbrahim: "Anayasa Mahkemesine Bireysel Başvuru ve Sorunlar", in Anayasa Mahkemesine Bireysel Başvuru: Anayasa Şikayeti/Anlamı ve Olası Sorunlar, TBB Yayını, Ankara 2011, s.81; GÖZTEPE, Ece: "Türkiye'de Anayasa Mahkemesi'ne Bireysel Başvuru Hakkının (Anayasa Şikâyeti) 6216 Sayılı Kanun Kapsamında Değerlendirilmesi", Türkiye Barolar Birliği Dergisi, 95, 2011, s.27; ERDİNÇ, Tahsin: "Karşılaştırmalı Olarak Türk Anayasa Mahkemesine Bireysel Başvuru Hakkı (Anayasa Şikâyeti)", Türkiye Adalet Akademisi Dergisi, 6(20), 2015, s.109-110; ATASOY, Hakan: "Bireysel Başvuruda Güncel Sorunlar", in Türkiye'de Anayasa Mahkemesine Bireysel Bașvuru (Anayasa Șikayeti), ed. Sevtap Yokuş, 2. Bask1, Seçkin, Ankara 2015, s.242-243; INNCEOĞLU, Sibel: Anayasa Mahkemesi'ne Bireysel Başvuru: Türkiye ve Latin Modelleri, On İki Levha, İstanbul 2017, s.191; KARAMAN, Ebru: Karşılaştırmalı Anayasa Yargısında Bireysel Başvuru Yolu, On İki Levha, İstanbul 2013, s.198.

2 Örn. bkz. ŞİRIN, Anayasa Mahkemesi Kararları Işı̆̆ında Bireysel Başvuru Hakkı, s.18-28; ŞíRİN, Tolga: Türkiye'de Anayasa Şikâyeti (Bireysel Başvuru): İnsan Hakları Avrupa Mahkemesi ve Almanya Uygulaması ile Mukayeseli Bir İnceleme, s.246-247; GÖZTEPE, s.28-29; ŞİMŞEK, Tacettin: "İdari Yarg1 Açısından Anayasa Mahkemesine Bireysel Başvuru Hakkı", in Anayasa Mahkemesine Bireysel Başvuru: Anayasa Şikayeti/Anlamı ve Olası Sorunlar, TBB Yayını, Ankara 2011, s.131; AYDIN, s.153; ATASOY, s.239-241; HAMDEMİ, Berkan: Anayasa Mahkemesine Bireysel Başvuru, 2. Bask1, Seçkin, Ankara 2018, s.186, 187; KARAMAN, s.127-128. Aksi görüş için. ERDİNÇ, s.96.

${ }^{3}$ GÖZTEPE, s.34-37.

${ }^{4}$ GÖZTEPE, s.25.

${ }^{5}$ GÖZTEPE, s.31-33; GÖZTEPE, Ece: “Ece Göztepe'nin Konuşması”, in Anayasa Mahkemesine Bireysel Başvuru: Anayasa Şikayeti/Anlamı ve Olası Sorunlar, TBB Yayını, Ankara 2011, s.36-37; AYDIN, s.140-141.

${ }^{6}$ GÖZLER, Kemal: Türk Anayasa Hukuku, 2. Bask1, Ekin, Bursa 2018, s.276-277.
} 
bir nitelendirmeye konu olmayan "hak", "özgürlük" ve "hürriyet" ifadelerini bireysel başvuruya konu olabilen temel hak ve özgürlüklerin ifade etmek için kullandığımızı belirtmek isteriz. Son olarak, hak ve özgürlük kavramları arasında da özel bir ayrım gözetmeyeceğiz. Daha doğrusu, hakkın olduğu her durumda bir tür özgürlüğün var olduğunu varsayacağız $z^{7}$. Bununla yanında, İngilizce unfreedom, yani özgür olmama durumunu "özgürsüzlük" ile karş1layacağız. "Özgürsüzlük" sözcüğü Türkçe sözlüklerde geçmemektedir. Bununla birlikte, "eşit" sıfatından türetilmiş "eşitsizlik" isminin varlığı düşünüldüğünde aynı eklerin kullanılmasıyla "özgürsüzlük" isminin de türetebileceği kanaatindeyiz ${ }^{8}$.

Son olarak, temel sorunu ifade edelim. Türk bireysel başvuru sisteminde temel hak ve özgürlük ihlali doğrudan bir kanundan kaynaklansa dahi, söz konusu kanunun uygulanmasına ilişkin birel idari işlem veya mahkeme kararı bulunmadığ 1 sürece bireysel başvuru yolu kapalı kalıyor. Kanun ile kişi arasına birel idari işlem veya yargı kararı girdikten ve dolayısıyla bireysel başvurunun önü açıldıktan sonra dahi, bireysel başvuruyu inceleyen Anayasa Mahkemesi bölümünün ihlale yol açan kanunu iptal etme yetkisi bulunmuyor. Çalışma sırasında bu düzenlemenin yaratabileceği sorunlar ve bu sorunları aşma yolları incelenecektir.

\section{II. İHLAL EDEN KANUNLARIN İPTAL EDÍLEMEMELERINIIN SAKINCALARI}

Öncelikle ilgili pozitif düzenlemeleri analım. Anayasanın 148/3 maddesine göre "Herkes, Anayasada güvence altına alınmış temel hak ve özgürlüklerinden, Avrupa İnsan Hakları Sözleşmesi kapsamındaki herhangi birinin kamu gücü tarafından, ihlal edildiği iddiasıyla Anayasa Mahkemesine başvurabilir. Başvuruda bulunabilmek için kanun yollarının tüketilmiş olması şarttır". Anayasa hükmündeki "kamu gücü" ifadesi hem kamusal merciler tarafindan ihdas edilen herhangi bir işlemi hem de bu mercilerin eylemlerini kapsayacak ölçüde geniştir. Bu geniş ifade 6216 sayılı Kanun'un 45/1 maddesinde "Herkes, Anayasada güvence altına alınmış temel hak ve özgürlüklerinden, Avrupa İnsan Hakları Sözleşmesi ve buna ek Türkiye'nin taraf olduğu protokoller kapsamındaki herhangi birinin kamu gücü tarafından, ihlal edildiği iddiasıyla Anayasa Mahkemesine başvurabilir" şeklinde tekrar edilmesine rağmen, aynı maddenin 3. fikrası "Yasama işlemleri ile düzenleyici idari işlemler aleyhine doğrudan bireysel başvuru yapılamayacağ 1 gibi, Anayasa mahkemesi kararları ile Anayasanın yargı denetimi dışında bıraktığı işlemler de bireysel başvurunun konusu olamaz" demek suretiyle aleyhine bireysel başvuruda bulunulacak olan işlemler kümesini daraltmış̧ır.

6216 sayılı Kanun'un 45/3 maddesinin Anayasanın 148/3 maddesine aykırı olduğu iddia edilmiştir ${ }^{9}$. Kanımızca bu iddia doğrudur. Nitekim ilgili kanun maddesi anayasal bir hükme istisna getirmekte, hükmün kapsamını daraltmaktadır. Üst norm bu yönde açık bir hüküm getirmedikçe bir normun istisnası ancak söz konusu normla aynı hiyerarşik seviyede veya bu normdan daha üst seviyede bulunan bir norm tarafindan getirilebilir ${ }^{10}$. Biz burada anayasaya aykırılık dışında bazı sorunlara dikkat çekmek istiyoruz.

Tespit ettiğimiz sorunlar "sistemin yönlendirme fonksiyonu açısından sorunlar" ve "temel hak ve özgürlüklerin korunması açısından sorunlar" olmak üzere iki ana başlık altında toplanabilir. $\mathrm{Bu}$ sorunlardan bir veya birkaçının yalnızca kanunlar değil, idarenin düzenleyici işlemleri açısından da geçerli olmasını bekleyebiliriz. Biz bu normlar açısından ayrı ayrı değerlendirme yapmayacak ve gerekli olursa sorunun idarenin düzenleyici işlemleri açısından da geçerli olacağını belirteceğiz. Tekrar hatırlatalım ki tespit edeceğimiz sorunlar hem kanunlara karşı doğrudan

\footnotetext{
${ }^{7} \mathrm{Bu}$ yaklaşımın pozitif statü hakları için ne derece yerinde olduğu tartışılabilir. Neticede hakkın tanındığı kişilerin özgürlüğünden genellikle negatif statü hakları söz konusu olduğunda bahsedilir. Bununla birlikte, pozitif statü haklarının hak sahibi kişilere "talep hakkı" tanıdığı kabul edildiğinde, pozitif statü hakları açısından bile bir tür özgürlükten, talep etme özgürlüğünden bahsetmek mümkün olabilir. Bu tartışmalı bir konudur. Ancak, bireysel başvuru kapsamında karşımıza çıkan hakların büyük çoğunluğu negatif statü hakkıdır. Dolayısıyla, hak-özgürlük özdeşleştirmesinin yerinde olmaması durumunda da bu makalede dikkat çekeceğimiz sorunun öneminden pek bir şey yitireceğini söyleyemeyiz.

${ }^{8}$ Bkz. SILLIER, Yıldız: "İki Özgürlük Anlayışı”, Felsefe Tartışmaları, 31, 2003, s.52, dn. 2. Sözcüğün kullanıldığı bir başka çalışma için bkz. GÜLMEZ, Mesut: “'Örgütlenme Özgürsüzlügü’ Cephesinde Yeni Bir Şey Yok! Olacağı da Yok", Çalışma ve Toplum, 2, 2013, s.15 vd.

9 AYDIN, s.145-146; SAĞLAM, s.28; ŞAHBAZ, s.81; GÖZTEPE, “Türkiye'de Anayasa Mahkemesi’ne Bireysel Başvuru Hakkının (Anayasa Şikâyeti) 6216 Sayılı Kanun Kapsamında Değerlendirilmesi”, s.27; ERDİNÇ, s.109-110.

${ }^{10}$ GÖZLER, Kemal: "Yorum İlkeleri”, in Anayasa Hukukunda Yorum ve Norm Somutlaştırması, ed. Ozan Ergül, Kamu Hukukçuları Platformu-Türkiye Barolar Birliği Ortak Yayını, Ankara 2013, s.44-45.
} 
bireysel başvuruda bulunulmasının engellenmesine hem de Anayasa Mahkemesinin ihlale yol açtığını tespit ettiği kanunu iptal etme yetkisinin bulunmamasına ilişkindir ${ }^{11}$.

\section{A. Sistemin Yönlendirme Fonksiyonu Açısından}

$\mathrm{Bu}$ kısımda öncelikle normatif sistemlerin eylemleri yönlendirme fonksiyonundan ve çatışan normların bu fonksiyon açısından sakıncalarından bahsedeceğiz. İkinci kısımda temel hak ve özgürlükleri ihlal eden kanunların bu genel çerçeve içindeki konumuna değinerek, bu kanunları geçersiz kılmanın mümkün olmamasının yol açabileceği sorunu ortaya koymuş olacağız.

1. Genel Çerçeve

Bir hukuk sisteminde içerik olarak birbiriyle çelişen normların bulunması ideal bir durum olarak görülmez. Nitekim bir norm muhataplarını " $\varphi$ " ile yükümlü kılarken bir başka normun aynı muhatabı " $\sim \varphi$ " ile yükümlü kılması durumunda muhatabın aynı anda her iki norma birden uyması mümkün değildir. $\mathrm{Bu}$ gibi durumlarda normlar arasında mantıksal çelişki olduğu ve normlardan birinin geçersiz olması gerektiği düşünülebilir. Oysa normlar arasındaki çatışmalar mantıksal çelişki arz etmez ${ }^{12}$. Olsa olsa söz konusu normları dile getiren normatif önermeler (normative propositions) arasındaki çatışma mantıksal olabilir ${ }^{13}$. Çatışan normatif önermelerden biri doğru ise diğeri yanlış olmak zorundadır. Normlar ise doğru veya yanlış değeri almazlar, geçerli veya geçersiz olurlar ${ }^{14}$. "Geçersiz norm" tamlaması kavramsal bir çelişki ifade eder; bir başka deyişle, geçersiz bir norm var olamaz. Öte yandan, bir önerme yanlış olsa dahi bir önerme olmaya devam eder $^{15}$. Dolayısıyla, çatışan normlar sorununu mantıksal çelişkiden farklı bir şekilde açıklamak gerekir.

Çatışan normlar aynı anda geçerli olabilecek olsalar dahi, bu durumun bir normatif sistem açısından niçin arzu edilir olmadığını başka açılardan da ortaya koyabiliriz. Her şeyden önce pratik normatif sistemler eylemi yönlendirme (guidance) fonksiyonunu yerine getirirler. Beklenen, muhatapların söz konusu sistemin normlarını dikkate alarak gerekli davranışı yerine getirmesidir. Yaptırım gibi cebrî uygulamalar bir normatif sistemin ancak ikincil fonksiyonu olabilir. Yaptırım tehdidi muhatabı bir norma uymaya yönlendirecek ek bir eylem sebebi (reason for action) sağlar. Normlar arasındaki çatışmalar normatif sistemin eylemleri yönlendirme fonksiyonu açısından kusur teşkil ederler. Nitekim, muhatap çatışan ve buna rağmen her ikisi de geçerli olan normlardan hangisine uyması gerektiği konusunda tereddüt yaşayabilir.

Durumu hukuk sistemleriyle bağdaştırarak ifade edecek olursak, genellikle hukuk devleti ilkesinin bir gereği olarak görülen hukuki öngörülebilirlik, normatif sistemlerin davranış1 yönlendirme fonksiyonu açısından önem arz eder. Muhatapların gelecekteki davranışlarını mevcut normlar aracılığıyla belirleyebilmesi ve düzenleyebilmesi gerekir. Eylemleri yönlendirmek hukuk sistemlerinin de birincil amacıdır ki geçmişe etkili, yani herhangi bir eylemi yönlendirme ihtimali bulunmayan, normların varlığına ancak istisnaen müsaade edilir.

2. Temel Hak ve Özgürlükleri İhlal Eden Kanunun Durumu

Aykııılık ve çatışma yakın anlamlı ancak farklı kavramlardır. Bu kavramların farklı kavramlar olduğu aykırılık niteliği taşımayan çatışmaların ve çatışma niteliği taşımayan aykırılıkların varlığıyla gösterilebilirr ${ }^{16}$. Buna göre, aykırılık yalnızca farklı hiyerarşik seviyedeki normlar arasında ortaya çıkar. Bir kanunun kanuna aykırı olduğundan bahsetmeyiz. Farklı hiyerarşik güçteki normlar arasındaki aykırılık "çatışma" şeklinde ortaya çıkabileceği gibi "aykırı biçimde ihdas edilme" şeklinde de ortaya çıkabilir. Buna göre, eğer farklı hiyerarşik güçteki normların içeriksel uyuşmazlığından bahsediyorsak ortada "çatışma şeklinde aykırılık" bulunur. Bununla birlikte, anayasal karar yetersayısına aykırı biçimde çıkarılmış bir kanun, içeriği anayasal hükümlerle uyumlu olsa dahi anayasaya aykırı olacaktır. Bu durumda ise "aykırı biçimde ihdas

\footnotetext{
${ }^{11}$ Aşağıda göreceğimiz gibi esasen Türk hukukunda temel hak ve özgürlükleri ihlal eden kanunun bireysel başvuru neticesinde geçersiz kılınmasının bir yolu mevcuttur. Ancak, bu yol dolambaçlı ve usul ekonomisine aykırı bir yoldur. Bu yolun kesin bir çözüm olduğunu söylemek de zordur.

${ }^{12}$ KELSEN, Hans: General Theory of Norms, çev. Michael Hartney, Clarendon Press, Oxford 1991, s.212-214.

${ }^{13}$ Normlar ve normatif önermelerin farkları ve deontik ifadelerin aynı anda hem bir normu hem de bir normatif önermeyi dile getirebilmesi hakkında bkz. BULYGIN, Eugenio: "Norms, Normative Propositions, and Legal Statements", in FLØISTAD, Guttorm: Philosophy of Action: Contemporary Philosophy (A New Survey), Cilt: 3, Martinus Nijhoff, Lahey 1982, s.127-128.

${ }^{14}$ BULYGIN, s.127-128; KELSEN, s.170-174.

${ }^{15}$ KELSEN, s.171.

${ }^{16}$ Biz daha önce bu farkı detaylı bir biçimde "Lex Superior İlkesi: Hukuki Geçerliliği ve Uygulaması" başlıklı kitabımızda inceledik. Burada kitaptaki açıklamaların ancak bir özetini sunabiliriz. Detaylı bir tartışma için. GÜLGEÇ, Yahya Berkol: Lex Superior İlkesi: Hukuki Geçerliliği ve Uygulaması, On İki Levha, İstanbul 2018, s.34-38.
} 
edilme" söz konusu olur. "Aykırı biçimde ihdas edilme" içeriksel sınırlara ilişkin de olabilir. Bu bağlamda temel hak ve özgürlükleri sınırlayan bir yönetmelikle anayasa arasında bu iki normun içeriği bağlamında bir aykırılık değil, "içerik şartlarına aykırı biçimde ihdas edilme" olarak ifade edebileceğimiz bir aykır1lık bulunur.

Buradan anlaşılabileceği üzere çatışma farklı hiyerarşik seviyedeki normlar arasında ortaya çıkabileceği gibi, aynı hiyerarşik düzeydeki normlar arasında da cereyan edebilir. Çatışmada mühim olan normların içerikleri, muhataplar açısından ifade ettikleri "olması gereken"ler arasındaki uyumsuzluktur. Dolayısıyla, bu bölümün başında verdiğimiz örneğe dayanarak " $\varphi$ " ve “ $\sim$ " yükümlülüklerini öngören iki normun arasında çatışma olduğunu söyleyebiliriz. Bu iki norm aynı hiyerarşik güçteyse "saf çatışma"dan, yani aykırılık niteliği taşımayan çatışmadan bahsedebiliriz. Aksi halde iki norm arasındaki uyumsuzluk "çatışma şeklinde aykırılık" olarak tarif edilmelidir.

Temel hak ve özgürlüklere aykırı bir kanun hem anayasayla çatışmak hem de anayasaya aykırı olmak zorundadır. Çatışma zorunluluğu şuradan gelir: Temel hak ve özgürlükleri ihlal eden bir kanun, anayasanın kiş̧ilere tanıdığı bir hak veya özgürlüğün söz konusu kişiler açısından bulunmadığını, en azından anayasanın tanıdığı kadar geniş biçimde bulunmadığını ilan eder. Örneğin, "herkes koşmakta özgürdür" diyen bir anayasa normu ile "herkes saatte on kilometre hızın altında koşmakta özgürdür" diyen bir kanun normu çatışmaktadır. Bununla birlikte, temel hak ve özgürlükleri ihlal eden bir kanun anayasaya aykırı da olmak zorundadır. Zaten temel hak ve özgürlüklere müdahale eden kanunu anayasaya aykırı hale getiren husus bizatihi müdahale değil, bu müdahalenin anayasaya aykırılığıdır. Bir başka deyişle, müdahale ancak hukuka (anayasaya) aykırıssa ihlal niteliği taşır. Dolayısıyla, "temel hak ve özgürlükleri ihlal eden" sıfatı zaten "anayasaya aykırılık" niteliğini de içinde taşımaktadır.

Temel hak ve özgürlükleri ihlal eden bir kanunun anayasa ile çatışmak (ve hatta ona aykırı olmak) zorunda olduğunu gördügümüze göre, bu normların iptal edilememesinin hem hukuk devleti, hukuki güvenlik ve hukuki belirlilik ilkelerine aykırı olacağını hem de bir normatif sistemin en temel fonksiyonu olan eylemleri yönlendirme yetisi açısından bir kusur teşkil ettiğini söyleyebiliriz. İhlalde bulunan kanun hâlâ bir kanundur. Anayasayla çatışan normlar uygulanmadıkça hukuk sisteminin niteliği açısından da aslî bir sorun olduğundan bahsedemeyiz. Ancak, ne kadar önemsiz olursa olsun çatışan normların varlığı hukuk sisteminin toplam etkinliğini ve etkililiğini düşürecektir. Burada etkinliği hukuk normlarıla ulaşılmak istenen sonuca ulaşılması, etkililiği ise hukuk normlarının öngördüğü yükümlülük ile muhatapların davranışları arasındaki uyum olarak kullanıyoruz. Etkinliği düşüren anayasal normlarla ulaşılmak istenen amaca (temel hak ve özgürlükleri anayasaya aykırı biçimde sınırlayan kanunların bulunmaması) ulaşılamamasıdır. Aynı zamanda sistemin toplam etkililiği de düşecektir. Nitekim kanuna uyarak daraltılmış özgürlük alanının dışına çıkmayan kişilerin eylemleri anayasay $1^{17}$, kanunu ihlal ederek anayasal özgürlük alanını esas alan kişileri davranışı ise kanunu daha etkisiz kılacaktır.

\section{B. Temel Hak ve Hürriyetlerin Korunması Açısından}

Bu kısımda temel olarak şunu ileri süreceğiz: Temel hak ve özgürlükleri ihlal eden kanun geçersiz kılınmadıkça ihlalin önüne geçmek mümkün değildir. Kanun iptal edilmedikçe ihlal hem başvurucu hem de kanun kapsamındaki diğer kişiler açısından devam edecektir.

Yukarıdaki iddia pek çok okuyucuya malumun ilanı gibi görünebilir. Ancak, görünüşe bakılırsa Türk kanun koyucusu için bu husus hiç de malum değildir. Türk kanun koyucusu bir kişinin bir hak veya hürriyetinin, ancak somut durumda söz konusu kişinin hak veya hürriyetten istifade etmesi engellenirse ihlal edileceğini düşünüyor gibidir. Dolayısıyla, konuyla ilgili bazı tartışmalar yürütmenin yerinde olacağını düşünüyoruz.

Bu iddiamızın doğruluğu temel hak ve özgürlük ihlalinin ne zaman gerçekleştiğine bağlıdır. Temel hak ve hürriyetin yalnızca somut durumda uygulama işlem ve eylemleriyle değil, aynı zamanda genel nitelikli normlarla ihlal edildiğini Matthew H. Kramer'ın özgürlük ve özgürsüzlük hakkındaki görüşlerine dayanarak açıklayacağız. Sonrasında Kramer'ın görüşleri doğrultusunda ulaşılan sonuçları Türk bireysel başvuru sistemine uygulayarak, bu sistemin çalışmanın giriş bölümünde zikredilen bir "tuhaflığına" değineceğiz.

\footnotetext{
${ }^{17}$ Bunun nedeni hak tanıyan normların yetki veren normlar olarak görülebilmesi ve yetki veren normların etkililiğinin etkinlikleri, yani bu normlarla amaçlanan hukuki sonuçlara ulaşılabilme yüzdesiyle ölçülebilecek olmasıdır. Bkz. MUNZER, Stephen: Legal Validity, Martinus Nijhoff, Lahey 1972, s.5.
} 


\section{1. Özgürlük ve Özgürsüzlük (Freedom and Unfreedom)}

Detaylı açıklamalara geçmeden önce özgürlük ve hak arasında bu çalışmada esas alınan ilişkiyi hatırlatmak isteriz. Birey hakkı olan menfaati elde etmek için davranmakta özgürdür. Buradaki özgürlügü de negatif özgürlük ${ }^{18}$, yani söz konusu menfaati elde etmek için gerçekleştirilen davranışın engellerden beri olmasını isteme hakkı olarak algılayabiliriz.

Kramer'ın özgürlüğe ilişkin ayrımı üçlü bir ayrımdır. Bir başka deyişle, insanların gerçekleştirmekte özgür olduğu ve olmadığı davranışlar geleneksel olarak tercih edildiği gibi ikiye değil, üçe ayrılarak incelenir. Bu ayrımı özgürlükler, özgürsüzlükler ve doğal özgürsüzlükler olarak ifade edebiliriz ${ }^{19}$. Bu bağlamda, özgürsüzlükler gerçekleştirmekte özgür olmadığımız bütün davranışları kapsamaz. Gerçekleştirmekte özgür olmadığımız davranışlar özgürsüzlükler ve doğal özgürsüzlüklerden oluşan birleşik bir kümedir. Öyleyse özgürlüklerden başlayarak bu farklı kategorileri görmekte yarar vardır.

Kramer, özgürlükleri "F Postulatı" ismini verdiği bir postulatla açıklar. Buradaki "F" harfi freedomı temsil etmektedir. Biz Türkçeleştirme açısından bu postulata "Ö postulatı", Kramer'ın "U Postulatı" ismini verdiği ve "U" harfinin unfreedomı temsil ettiği postulata ise "ÖS postulatı" (Özgürsüzlük Postulatı) ismini vereceğiz. Buna göre Ö postulatı şu şekildedir:

"Bir kimse yalnızca $\varphi$ yapma yetisine sahipse $\varphi$ yapmakta özgürdür" 20

Postulattan da anlaşılabileceği üzere buradaki özgürlük formülasyonu deontik, yani normatif değil kiplikli (modal) ya da olgusal bir özgürlük anlayışıdır ${ }^{21}$. Bir başka deyişle, belirlenen bir kimsenin neyi yapmakta özgür olması gerektiği değil, neyi yapmakta özgür olduğudur. Benzer bir biçimde postulatın belirlediği bir kimsenin belli bir davranışı gerçekleştirmek için izne sahip olup olmadığ 1 değil, gerçekleştirip gerçekleştiremeyeceğidir. Hukuk felsefesinde sık başvurulan bir örnekle açıklayacak olursak, eli silahlı haydudun muhataba bütün parasını ona vermesini emretmesi, emrin muhatabının deontik özgürlüğünü etkilemeyebilir. Ancak, kiplikli özgürlügünü etkileyecektir. Bu farktan yola çıkarak Ö postulatının normatif bir düzen olan hukuk sisteminde uygulama bulamayacağı düşünülmemelidir. Her şeyden önce, Kramer'ın da belirttiği gibi, kiplikli ve deontik özgürlük durumları örtüşebilir ${ }^{22}$. Örneğin, cinayet işleyenin hukuk düzeni tarafından ağır yaptırımlara tabi tutulacağını bilmesi cinayet işleme özgürlüğünü kısıtlar. Aynı zamanda, cinayeti yasaklayan ahlak ve hukuk normları nedeniyle bu kişi deontik olarak da cinayet işlemekte özgür değildir. Bununla birlikte, cinayetin hukuk düzeni veya pozitif ahlak tarafindan yasaklanmamış olduğu bir durumda aynı kişi cinayet işlemekte kiplikli anlamda özgür olsa da, deontik anlamda özgür olmayacaktır.

İkinci olarak, Ö postulatının bir kimsenin belli bir davranışı gerçekleștirmekte fiziksel olarak sınırlandırılmamış olduğu anlamına geldiğini, ancak buradaki "fiziksel" ifadesinin zihinsel veya psikolojik sınırları dışlamadığını belirtelim ${ }^{23}$. Bu anlamda, psikolojik veya zihinsel sebeplerle belli bir davranışı gerçekleştirme yetisi engellenmiş olan kişinin söz konusu davranışı gerçekleştirmekte özgür olduğu söylenemez.

ÖS postulatına göre izleyen iki şart birlikte gerçekleşirse özgürsüzlük söz konusu olacaktır: 1) Kişinin ikinci şartın gıyabında $\varphi$ yapmakta özgür olacak olması ve 2) $\varphi$ yapmayı isteyip istememesinden bağımsız olarak, başka bir kişinin tasarrufları (dispositions) doğrultusunda $\varphi$ yapmasının engellenmiş olmasi ${ }^{24}$.

Burada bizim açımızdan önemli olan birkaç hususun altını çizmekte yarar var. İlk şartın

\footnotetext{
${ }^{18}$ Haliyle negatif özgürlük anlayışının yeterliliği ve meşruiyeti başta Marksist ve cumhuriyetçi ( republicanist) yazarlar olmak üzere pek çok düşünür tarafından sorgulanmıştır (Cumhuriyetçi eleştiri için Quentin Skinner'ın izleyen çalışması örnek gösterilebilir: SKINNER, Quentin: "The Idea of Negative Liberty: Philosophical and Historical Perspectives", in RORTY, Richard/SCHNEEWIND, Jerome B./SKINNER, Quentin: Philosophy in History: Essays on the Historiography of Philosophy, Cambridge University Press, Cambridge 1984, s.193-221). Biz burada bu tartışmayı ele almayacağız. Ancak, Avrupa İnsan Hakları Sözleşmesi ve Türk Anayasasında yer alan hak ve özgürlüklerinin büyük bir çoğunluğunun negatif özgürlük olarak tanımlanmış olmasına dayanarak Kramer'ın görüşü ile temel hak ve özgürlüklerin korunması arasında kuracağımız bağlantının sorun yaratmayacağını düşünüyoruz.

${ }^{19}$ KRAMER, Matthew H.: "Freedom and the Rule of Law", Alabama Law Review, 61(4), 2010, s.828.

${ }^{20}$ KRAMER, Matthew H.: The Quality of Freedom, Oxford University Press, Oxford 2003, s.3; KRAMER, "Freedom and the Rule of Law", s.828; KRAMER, Matthew H.: "On the Counterfactual Dimension of Negative Liberty", Politics, Philosophy \& Economics, 2 (1), 2003, s.64.

${ }^{21}$ KRAMER, The Quality of Freedom, s.3; KRAMER, "Freedom and the Rule of Law", s.835.

${ }^{22}$ KRAMER, "Freedom and the Rule of Law", s.836.

${ }^{23}$ KRAMER, "Freedom and the Rule of Law", s.835-836; KRAMER, The Quality of Freedom, s.60.

${ }^{24}$ KRAMER, The Quality of Freedom, s.3; KRAMER, "Freedom and the Rule of Law", s.828; KRAMER, "On the Counterfactual Dimension of Negative Liberty", s.64.
} 
önemi özgürsüzlükler ve doğal özgürsüzlükler arasındaki ayrımı ortaya koymasıdır. Buna göre, doğal özgürsüzlüğün söz konusu olduğu bir yerde özgürsüzlükten bahsedilemeyecektir. İkinci olarak, belli bir davranışı gerçekleştirmek konusunda özgür olup olmamanın kişinin bu konudaki istek ve arzularından bağımsız hâle getirildiğini de akılda tutmak gerekir. Son olarak dikkat çekmek istediğimiz önemli bir husus var. Kramer postulatların formülasyonunda "engellenmek" (to be prevented) ifadesini kullanır. Aynı zamanda özgürlükleri bir "yeti” (ability) olarak açıkladığı düşünüldüğünde, okuyucu bir kimsenin belli bir davranışı gerçekleştirebildiği sürece, bu davranışın önündeki engellerden bağımsız olarak, özgür olduğunu düşünebilir. Biz Kramer'ın ifadesinin bu şekilde yorumlanmaması gerektiğini düşünüyoruz. Bunun iki temel sebebi var. İlk olarak, Kramer'ın negatif özgürlük anlayışını benimsediğini hatırlamalıyız ${ }^{25}$. Thomas Hobbes'un özgürlük anlayışını hatırlayacak olursak, özgürlüğü bir davranışın önündeki engellerin yokluğu olarak tanımlayabiliriz ${ }^{26}$. Dolayısıyla, bir kimsenin belli davranışı gerçekleştirme özgürlügü olmadığını söyleyebilmek için kişinin davranışı gerçekleştirmeye teşebbüs ettiğinde mutlaka başarısız olması gerekmez. Kramer'ın "önlenme” ifadesini de bu doğrultuda mutlak olmayan bir önlenme, davranışı gerçekleştirme yetisini kısıtlayan bir engel olarak yorumlamak gerekir. İkinci olarak, bir yerde Kramer belli bir davranışı engellemenin failin bu davranışı gerçekleştirme gücüne engel teşkil etmek (impede) olduğunu ima eder ${ }^{27}$. Bu nedenle biz de herhangi bir yanlış anlaşılmayı engellemek amacıyla postulatların ifadesinde "engellemek" fiilini kullanmaktan kaçındık.

Özgürlüğe ilişkin kategorilerin üçüncüsü doğal özgürsüzlüklerden oluşur. Buna göre, bir kişinin doğal sınırlar nedeniyle davranışı gerçekleştiremeyecek olması doğal özgürsüzlük durumunu teşkil eder ${ }^{28}$. Örneğin, hiçbir insan 1şık hızından hızlı koşmakta özgür olamaz. Bunun nedeni hiçbir insanda bu yetinin bulunamayacak olmasıdır. Anlaşılacağı üzere, doğal özgürsüzlükler başka bir kimsenin istek, talimat ve arzularına bağlı değildir. Üstelik, bu tür özgürsüzlükler kapsam bakımından da sınırsızdır ${ }^{29}$. Bütün eylemler kümesi sonsuz elemanlıysa, doğal özgürsüzlük kapsamındaki eylemler de sınırlı sonsuz sayıda olacaktır. Doğal özgürsüzlükler bizim tartışmamız açısından önemli olmayacak. Bu nedenle detaylı açıklamalardan kaçınıyoruz.

Kramer'in tespitlerinde ele almak istediğimiz son bir husus özgürlük durumundan özgürsüzlük durumuna geçişin zamanına ilişkindir. Bu tartışma için tehdit durumunu örnek olarak alacağız. Kramer tehdit altında olan kişinin özgürlüğünün kısıtlanacağından emindir. Bununla birlikte, siyaset felsefecileri arasında bu kısıtlanmanın ne zaman ortaya çıktığına dair tartışma olduğunu not eder $^{30}$. Kişinin belli bir davranışı gerçekleştirmesi durumunda bir kötülükle ${ }^{31}$ karşılaşacağı yönünde tehdit edildiğini varsayalım. Burada tehdidin kaynağı önemsizdir. Tehdidin kaynağı bir devlet organı olabileceği gibi özel bir kişi de olabilir. Kramer'a göre, böyle bir durumda kişinin özgürsüzlüğü tehditte bulunan kişinin emrini hiçe sayacak ve dolayısıyla tehditte bulunan kimsenin yaptırım uygulamasına yol açabilecek herhangi bir davranışı gerçekleştirme yetisinin önündeki engellerden kaynaklanır ${ }^{32}$. Bazı teorisyenler özgürlük durumundan özgürsüzlük durumuna geçişin yaptırımın veya tehdidin konusu olan olumsuzluğun uygulanmasıyla gerçekleştiğini düşünerek hata etmektedirler ${ }^{33}$. Bu görüşün kabul edilmesi durumunda tehditte bulunan kişinin isteklerine boyun eğen kişinin, bu kişiye yaptırım uygulanmayacağı veya bu kişi herhangi bir kötülükle karşılaşmayacağı için, özgür olduğu düşünülecektir ${ }^{34}$. Buna ek olarak, hâlihazırda tehdide konu olan davranışı hiç gerçekleştirmek istemeyen kimselerin de özgür kabul edilmesi gerektiği söylenebilir. Oysa ÖS postulatı hatırlanacak olursa, özgürsüzlük durumunun kişinin isteklerine veya diğer kişinin istek, emir veya arzularına uyup uymamasına bağlı olmadığı görülecektir ${ }^{35}$.

\footnotetext{
${ }^{25}$ KRAMER, The Quality of Freedom, s.2.

${ }^{26}$ Bkz. HOBBES, Thomas: Leviathan, çev. Semih Lim, Yapı Kredi Yayınları, İstanbul 2013, s.162-163.

${ }^{27}$ KRAMER, The Quality of Freedom, s.3.

${ }^{28}$ KRAMER, "Freedom and the Rule of Law", s.828-829; KRAMER, The Quality of Freedom, s.42.

${ }^{29}$ KRAMER, "Freedom and the Rule of Law", s.828-829.

${ }^{30}$ KRAMER, The Quality of Freedom, s.194.

${ }^{31}$ Austin yaptırımı kötülük tehdidi olarak algılar ve bir irade açıklamasını emir yapanın, söz konusu irade açıklamasının içeriği değil, bu irade açıklamasına eşlik eden kötülük tehdidi olduğunu vurgular. Bkz. AUSTIN, John: The Province of Jurisprudence Determined, ed. Wilfrid Ed. Rumble, Cambridge University Press, Cambridge 2001, s.21.

${ }^{32}$ KRAMER, The Quality of Freedom, s.203-204.

${ }^{33}$ KRAMER, The Quality of Freedom, s.205.

${ }^{34}$ KRAMER, The Quality of Freedom, s.205-206.

${ }^{35}$ Ayrica bkz. KRAMER, The Quality of Freedom, s.205.
} 
Bu noktadan sonra Kramer özgürsüzlüğün başlangıcı olarak tehdidin gerçekleştirilmesinin mi yoksa bu tehdidin muhatap tarafından öğrenilmesinin mi esas alınması gerektiğini sorar ${ }^{36}$. Burada Kramer'ın açıklamalarını özetlemekle yetiniyoruz ${ }^{37}$. Özgürlüğün belli bir davranışta bulunma yetisi ve bu yetinin önündeki engeller olarak anladığımızı hatırlayalım. Bu objektif bir özgürlük anlayışıdır. Bir başka deyişle, özgürlüğü değerlendirilen kişinin davranışının önündeki engellerden haberdar olması gerekmez. Bu nedenle de özgürlük durumundan özgürsüzlük durumuna geçişin tehdidin muhatap tarafından öğrenildiği andan önce, tehdit niyetinin varlık kazanmasıyla gerçekleşeceğini düşünebiliriz. Bununla birlikte, Kramer haklı biçimde belli şartlar altında muhatap tarafından tehdidin öğrenildiği anın da önem taşıyabileceğini belirtir ${ }^{38}$. Bunun sebebi tehditte bulunan kişinin, tehdidinden haberdar olmayan birine yaptırım uygulama veya kötülük etme niyeti olmayabilecek olmasıdır. Bununla birlikte, burada tehditte bulunan kimsenin muhatabın tehditten haberdar olmadığını bilmesi de önemlidir. Dolayısıyla, tehditte bulunan kişinin muhatabın tehditten haberdar olmadığını bildiği ve haberdar olmayan muhatap veya muhataplara yaptırım uygulama veya kötülük etme niyetinin bulunmadığı durumlarda, ve yalnızca bu durumlarda, tehdidin öğrenildiği anın özgürsüzlüğün başladığı an olarak kabul edilmesi mümkündür. Son olarak, Kramer'ın özgürlüğün sınırlandığı an olarak tehditte bulunulduğu anın değil, emre veya isteklere aykırı davrananlara yaptırım uygulama veya kötülük etme niyetinin ortaya çıktığı anın esas alınması gerektiğini düşündüğünü belirtelim ${ }^{39}$.

\section{Kanunlar ve İhlal}

Şimdi Kramer'ın özgürlük anlayışını kanunlar tarafından gerçekleştirilen özgürlük ihlaline uyarlayacağız. İlk olarak, şu kadarı açık olmalı ki temel hak ve özgürlüklerin ihlali bu hak ve özgürlükleri anayasaya aykırı biçimde sınırlandıran kanunun somut durumda kişilere uygulanmasıyla gerçekleşmez. Bunun iki nedeni var. Öncelikle, özgürlüğün kısıtlanması için genel nitelikli bir norm tarafından öngörülen "kötülüğün" kişiye uygulanması, bir başka deyişle kişinin zor kullanmak, izin vermemek vb. şekillerde bir özgürlüğü kullanmasının önüne geçilmiş olması gerekmez ${ }^{40}$. İkinci olarak, yukarıda gördüğ̈̈müz gibi, özgürsüzlük dönemi genel olarak tehdit niyetinin ortaya çıkması ve bazı durumlarda da tehditten muhatabın haberdar olması anında başlar.

Türk hukukunda Resmi Gazete'de yayınlanma şartı kanunların geçerlilik şartı değil, yürürlük şartı olarak kabul edilir ${ }^{41}$. Türk hukuk sistemindeki yayınlanma, muhatabın tehditten haberdar edilmesi anlamına gelir. Aslında muhatap söz konusu tehditten haberdar olmasa bile, bu husus yetkililerin söz konusu kanunu muhataba uygulama niyetinde herhangi bir değişikliğe yol açmaz. Dolayısıyla, Türk hukukunda özgürsüzlük döneminin başlangıcının muhatap tarafından tehdidin öğrenilme anı değil, tehditte bulunan organın bu tehdidi duyurma anı olacağını söyleyebiliriz. Elbette bu analizde hukuk yetkililerinin hukuka uyacağını, yani yayınlanmamış bir kanun dolayısıyla kimseye yaptırım uygulama niyeti taşımayacağını varsayıyoruz.

Yukarıdaki açıklamalardan anlaşılacağı üzere, Türk hukukunda bir temel hak ve özgürlük ihlali, anayasaya aykırı biçimde bu hak ve özgürlüklere müdahale eden kanunun yayınlanmasıyla başlıyor. Zaman açısından kanunlar aracılığıyla ihlali gördükten sonra, bir de muhatap açısından ihlale dikkat çekmemiz gerekir. Söz konusu kanunlar, kısıtlanan özgürlüğün kapsamına giren davranış veya davranışların muhataplar tarafından gerçekleştirilmek istenip istenmemesinden

\footnotetext{
${ }^{36}$ KRAMER, The Quality of Freedom, s.205-206.

${ }^{37}$ Bkz KRAMER, The Quality of Freedom, s.205-208.

${ }^{38}$ KRAMER, The Quality of Freedom, s.207.

${ }^{39}$ KRAMER, The Quality of Freedom, s.208-209.

${ }^{40}$ Tolga Şirin yasama organının büyük ihtimalle doğrudan kanunla bir temel hak ve hürriyetin ihlal edilemeyeceğini düşündüğünü vurguladıktan sonra bu varsayımı eleștirmektedir. Buna göre, bazı yasalar uygulandıkları anda temel hak ve hürriyetleri ihlal ederler. Bu yasaların somut durumda kişilere uygulanmasını beklemek onların "potansiyel mağduriyetlerini kabul etmek demektir" (bkz. ŞİRİN, Türkiye'de Anayasa Şikâyeti (Bireysel Başvuru): İnsan Hakları Avrupa Mahkemesi ve Almanya Uygulamas1 ile Mukayeseli Bir İnceleme, s.85). Biz de, eğer yasama organı bu varsayımı benimsemişse, varsayımın hatalı olduğunu düşünüyoruz. Sanıyoruz "potansiyel mağduriyetlerini kabul etmek" ifadesiyle vurgulanan geçerli bir kanunun uygulanmasının hak ihlaline yol açacağı durumlarda bireysel başvuru için uygulama işlemini beklemenin yerinde olmayacağı, böyle bir tercihin, amacı temel hak ve özgürlükleri korumak olan bir sistemin etkinliğini düşüreceğidir. Bu argümana katılmak mümkündür. Ancak, argüman bu hâliyle yalnızca temel hak ve özgürlüklerin etkin biçimde korunması için, ihlalin somut olarak ortaya çıkmasından önce harekete geçebilmenin mümkün olması gerektiğini ifade etmektedir. Bu bakış açısıyla geçerli bir biçimde ihdas edilmiş olmakla birlikte hiçbir zaman uygulanmayan bir kanun temel hak ve özgürlükleri ihlal etmeyecektir. Bizim Kramer'ın özgürsüzlük anlayışından yola çıkarak yapacağımız yorum temel ihlalin kanunun ihdasıyla başladığını ve ihlalin ortaya çıkması için uygulama işlemine gerek olmadığını ortaya koyacaktır.

${ }^{41}$ GÖZLER, Türk Anayasa Hukuku, s.655-656.
} 
bağımsız olarak - ÖS postulatının ikinci ayağı - tüm muhatapların temel hak ve özgürlüklerini ihlal eder.

Hal böyleyken, 6216 sayılı Kanun'un kanunlara karşı doğrudan bireysel başvuru yapılmasının önüne geçmesinin niçin anlaşılamayacağı ortadadır. 6216 sayılı Kanun kapsamında sanki bir temel hak ve hürriyetin ancak birel işlemler niteliğindeki idari işlem ve yargı kararlarıyla ihlal edilebileceği düşünülmektedir. Bir başka olasıllğa göre, kanun koyucu kanunların tek başlarına temel hak ve özgürlükleri ihlal ettiğinin pekâlâ bilincindedir. Bununla birlikte, bu ihlale karşı herkesin değil, yalnızca somut durumda ihlalden "canı yananların" bireysel başvuruda bulunabilmesini kabul etmektedir. Neticede temel hak ve hürriyetlerin ihlali herkes açısından sorun yaratmayabilir. Korunmak istenen objektif olarak temel hak ve hürriyetler olmayıp, bertaraf edilmek istenen bu hak ve hürriyetlerden faydalanmak isteyenlerin can sıkıntısıdır.

Şu durumda Türk bireysel başvuru sistemi yalnızca geçerli bir kanunun hukuka aykırı biçimde getirdiği kısıtlamayı ihlal eden ve bunun sonucunda birel işlemlerin muhatabı olan (idari para cezası alan, mahkûm edilen vb.) kişilerin haklarını korumaktadır. Eğer bireysel başvuru neticesinde ihlale neden olan kanun iptal edilemezse, hem başvurucu hem de kanunun muhatab1 olan diğer kişiler açısından ihlal devam edecektir. Hatta bir açıdan, hakkı korunmayan diğer kişilerin bir hukuk sisteminin kendilerinden beklediğini yapan, geçerli bir kanuna uyan kimseler olduğunu söyleyebiliriz.

Burada okuyucunun aklına şu soru gelebilir: Anayasaya aykırı kanunların ve düzenleyici işlemlerin iptali için ayrı bir usul öngörülmüştür. Bu usul işletilerek ihlaller giderilebilecekken bireysel başvuru sürecine bunların da dâhil edilmesine gerek var mıdır? Bu soruya şöyle bir cevap verilebileceği kanısındayız: Kanunların iptali için temel hak ve özgürlüğü ihlal edilen kişilerin yapabileceği tek şey kanunun ihlale sebep olan hükmünün kendilerine uygulanmasından sonra ${ }^{42}$ somut norm denetimini işletme teşebbüsünde bulunmaktır. Dolayısıyla, kanunlar açısından somut norm denetiminin hayata geçirilme şartları ile bireysel başvurunun şartları örtüşmektedir: İki durumda da öncelikle kanunun somut durumda kişiye uygulanması veya uygulanacak olması gerekmektedir. Dolayısıyla, somut norm denetimi yoluyla önüne gelecek olan kanunları iptal etmesi gerekecek olan Anayasa Mahkemesinin, bireysel başvuru nedeniyle bu yetkisini kullanamayacak olmasının ardındaki sebebi anlamak güçtür. Elbette, bireysel başvurulara bakmakla Anayasa Mahkemesi'nin bölümleri görevli kılınmışken, iptal davalarını çözüme bağlamak Genel Kurul'un yetki ve görev alanına girer. Yine de temel hak ve özgürlükleri korumak için kanunların iptali için etkin bir mekanizma bu kadar gerekliyken, bu sorunun yanıtsız bırakılması, üstelik kanunlar aleyhine doğrudan bireysel başvuru gerçekleştirilememesi isabetsiz olmuştur ${ }^{43}$. Biz ilerleyen bölümde mevcut sistemde bu sorunu atlatmanın hukuka uygun bir yolu olup olmadığını tartışacağız.

\section{OLASI ÇÖZÜM YOLLARI}

Kanunlara karşı doğrudan bireysel başvurunun önünün kapatılması ve temel hak ve özgürlükleri ihlal eden kanunların iptal edilememesinin yol açacağı sorunları gördük. Bu kısımda gerek pozitif hukuk kapsamında gerekse gerekli kanuni ve anayasal değişikliklerin yapılmasıyla bu sorunların giderilme yollarına değineceğiz. Bu çözüm yollarının bir kısmı doktrinde önerilmiş ve tartışılmıştır.

\section{A. Bireysel Başvuruyu İnceleyen Anayasa Mahkemesi Bölümü Tarafindan Genel Kurul'da İptal Davası Açılması}

6216 sayılı Kanun'un taslağı incelemede bulunan bölümün Anayasa Mahkemesi Genel Kurulunda ihlal eden kanun aleyhine iptal davası açabilmesini öngörüyordu. İlgili madde şu şekildeydi: "Bölümler bireysel başvuru incelemesi sırasinda temel hak ihlalinin kanun veya kanun hükmünde kararname hükümlerinden kaynaklandiğg kanaatine varırlarsa, bu kanun hükmünün ya da kanun hükmünde kararname hükmünün iptali istemiyle Genel Kurula başvururlar". Eğer bu tasarı kanunlaşmış olsaydı, Ece Göztepe'nin de dikkat çektiği gibi, sistem içi bütünlük sağlanacak ${ }^{44}$, çatışan normlara ilişkin sorun giderilecekti. Ayrıca, en nihayetinde temel hak ve özgürlükleri ihlal eden kanun geçersiz kılınabileceği için, temel hak ve özgürlükler yalnızca

\footnotetext{
${ }^{42}$ Davadan önce bir kanun hükmünün bir kimseye uygulanmış olması şart olmayabilir. Somut norm denetiminde mühim olan karara esas alınacak olan bir kanunun anayasaya aykırılı̆̆ı olduğundan, temel hak ve özgürlük ihlaliyle doğrudan ilgisi olmayan bir dava sırasında da kişinin temel hak ve özgürlüklerini ihlal edecek bir kanunun uygulanması söz konusu olabilir.

${ }^{43}$ Benzer bir değerlendirme Cumhurbaşkanlı̆̆ kararnameleri açısından yapılabilir.

${ }^{44}$ GÖZTEPE, “Ece Göztepe'nin Konuşması”, s.37.
} 
başvuru sahibi değil, bütün ilgili kişiler açısından korunmuş olacaktı.

Alt Komisyonda muhalefet üyelerinin öne sürdüğü gerekçe bu hükümle Anayasaya aykırı bir biçimde, iptal davası açmanın yeni bir yolunun belirleniyor olmasıyd ${ }^{45}$. Ece Göztepe Alt Komisyon raporunda yasama organının ilgili kanunu yürürlükten kaldıracağı yönündeki tespiti naif bulmuştur ${ }^{46}$ ve kanımızca bu görüşünde de sonuna kadar haklıdır. Soyut ve somut norm denetimi yasama organına güvenmekle yetinmeyip, Anayasa Mahkemesinin anayasaya aykırı kanunları geçersiz kılabilmesine imkân tanırken, temel hak ve özgürlüklere aykırılık gibi önemli bir konuda takdirin yasama organına bırakılması kuşkulu bir tercih olmuştur.

Ece Göztepe bir başka çalışmasında bölümlerin temel hak ve özgürlükleri ihlal eden kanunlar aleyhine Genel Kurula yapılacak olan başvuruyu "somut norm denetimi" kapsamında değerlendirmektedir ${ }^{47}$. Eğer bu yorum doğruysa, "davaya bakmakta olan mahkeme" konumundaki bölümün kanuni herhangi bir yetkilendirmeye ihtiyaç duymadan, Anayasanın somut norm denetimine ilişkin 152. maddesi uyarınca Genel Kurul'a başvurabilmesi gerekir. Bu durumda Alt Komisyon'daki gerekçenin aksine, esasen anayasaya aykırı bir biçimde yeni bir iptal davası açma usulü öngörüldüğü de söylenemez. Tolga Şirin de bireysel başvuruya bakan bölümün anayasaya aykırı gördüğü kanunun aleyhine Genel Kurula yapılacak olan bir başvuruyu iptal davası olarak görmez. Yazara göre bunun sebebi iptal davasının yargı dışı özneler tarafından Anayasa Mahkemesine yapılan başvuruya verilen isim olmasıdır ${ }^{48}$.

Bununla birlikte, bölümlerin Genel Kurula yapacağı başvurunun "somut norm denetimi" kapsamında görülmesi mümkün değildir. Öncelikle somut norm denetiminin şartlarını hatırlayalım: 1) Ortada görülmekte olan bir dava olacak, 2) Davaya bakmakta olan bir mahkeme olacak ve 3) anayasaya aykırılığı iddia edilecek olan norm davada uygulanacak bir norm olacak. Genel olarak bireysel başvurunun bir dava olduğu düşünülmektedir ${ }^{49}$. Keza davaya bakmakta olan merciin de bir mahkeme olduğu söylenebiliir ${ }^{50}$. Bununla birlikte, temel hak ve özgürlükleri ihlal eden kanun davada Anayasa Mahkemesi bölümü tarafından uygulanacak bir kanun değildir ${ }^{51}$. Bir kanunun uygulanacak olması, söz konusu kanunun mahkemenin karar veya kararlarına dayanak oluşturacak olmasıdır. Anayasa Mahkemesi bölümü ise bireysel başvuru sırasında temel hak ve özgürlük ihlali olup olmadığına kanunu uygulayarak karar verecek değildir. Uygulanacak olan anayasal normlar ve mahkemenin görev ve işleyişini düzenleyen 6216 sayılı Kanun'dur. Dolayısıyla, eğer anayasa aykırılık 6216 sayılı Kanun açısından ortaya çıkarsa, örneğin bireysel başvuruyu inceleyen bölüm 6216 sayılı Kanun'un 45/3 maddesinin anayasaya aykırı olduğu kanaatine varırsa, bu madde aleyhine somut norm denetimine gidebilir. Nitekim bireysel başvurunun kabul edilebilir olup olmadığına karar verirken bu maddeyi uygulayacaktır. Bu anlamda Anayasa Komisyonu Raporunda önerilen hüküm ile itiraz yolunun karşılaştırılmasının da yerinde olmadığını eklemeliyiz ${ }^{52}$.

Netice itibariyle, bölümün Genel Kurula başvurusunun somut norm denetimi teşkil etmeyeceğini söyleyebiliriz. Bu durumda tasarıda yer alan ve çıkarılan hükmün soyut norm denetimini örneklendirdiğini kabul edebiliriz. Anayasanın 150. maddesi kimlerin soyut norm

\footnotetext{
${ }^{45}$ Bkz. Anayasa Mahkemesinin Kuruluşu ve Yargılama Usûlleri Hakkında Kanun Tasarısı ile Anayasa Komisyonu Raporu (1/993), Dönem: 23, Tarih: 11 Ocak 2011, https://www.tbmm.gov.tr/sirasayi/donem23/yil01/ss696.pdf, Erişim Tarihi: 28 Ağustos 2020, s.20.

${ }^{46}$ GÖZTEPE, "Ece Göztepe'nin Konuşması", s.37.

${ }^{47}$ GÖZTEPE, “Türkiye'de Anayasa Mahkemesi'ne Bireysel Başvuru Hakkının (Anayasa Şikâyeti) 6216 Sayılı Kanun Kapsamında Değerlendirilmesi”, s.32; GÖZTEPE, “Ece Göztepe'nin Konuşması”, s.37.

48 ŞİRIN, Türkiye'de Anayasa Şikâyeti (Bireysel Başvuru): İnsan Hakları Avrupa Mahkemesi ve Almanya Uygulaması ile Mukayeseli Bir İnceleme, s.281.

49 Örn. bkz. KILINÇ, Bahadır: "Karşılaştırmalı Anayasa Yargısında Bireysel Başvuru (Anayasa Şikâyeti) Kurumu ve Türkiye Açısından Uygulanabilirliği", Anayasa Yargıs1, 25, 2008, s.23; AYDIN, s.125; SAĞLAM, s.20; ŞAHBAZ, s.73; İNCEOĞLU, s.197.

50 İNCEOĞLU, s.196. Bununla birlikte, Kemal Gözler aksi görüştedir. Yazara göre, bireysel başvuruyu değerlendiren bölümler Anayasanın 152. maddesi kapsamında "davaya bakmakta olan mahkeme" olarak değerlendirilemez. Ne bireysel başvuru bir davadır ne de Anayasa Mahkemesi bölümleri birer mahkeme. Bkz. GÖZLER, Türk Anayasa Hukuku, s.1075,1083. Biz zaten Kemal Gözler'in de dikkat çektiği gibi (bkz. GÖZLER, Türk Anayasa Hukuku, s.1083), temel hak ve özgürlükleri ihlal eden kanunun bir bireysel başvuruda "davada uygulanacak olan kanun" olmadığını savunup bireysel başvuru sırasında somut norm denetimine gidilebileceğini reddedeceğimiz için tartışmanın detaylarına girmedik.

${ }^{51}$ GÖZLER, Türk Anayasa Hukuku, s.1083. Aksi görüş için bkz. İNCEOĞLU, ss.197-199.

${ }^{52}$ Anayasa Mahkemesinin Kuruluşu ve Yargılama Usûlleri Hakkında Kanun Tasarısı ile Anayasa Komisyonu Raporu (1/993), Dönem: 23, Tarih: 11 Ocak 2011, https://www.tbmm.gov.tr/sirasayi/donem23/yil01/ss696.pdf, Erişim Tarihi: 28 Ağustos 2020, s.20.
} 
denetimi için Anayasa Mahkemesi'ne başvurabileceğini belirlemiştir. Kanunla sınırlı sayıda belirlenmiş olan bu kişilerin genişletilmesi anayasaya aykırılık teşkil edecektir. Dolayısıyla, Alt Komisyon'un "anayasaya aykırılık" argümanının geçerli olduğunu ve tasarıdaki hükmün çıarılmasının hukuken doğru bir tercih olduğunu söyleyebiliriz ${ }^{53}$.

Bununla birlikte, Alt Komisyon'un hukuken doğru tercihi maalesef sorunumuzu çözmemekte, anayasaya aykırı kanunun iptal edilmesi gerekliliği karşımızda durmaya devam etmektedir. Bu noktada anayasa değişikliğiyle bireysel başvuru sırasında anayasaya aykırı olduğu tespit edilen kanun aleyhine bölümler tarafindan Genel Kurulda iptal davası açılmasının ayrıca öngörülmesi düşünülebilir. Kanımızca bu çözüm hukuken de isabetli olacaktır. Bu noktada Almanya, Macaristan ve Avusturya'nın bireysel başvuru sistemlerini örnek verebiliriz. Bu sistemlerde temel hak ve özgürlükleri ihlal eden kanunun anayasa mahkemeleri tarafindan geçersiz k1lınması mümkündür ${ }^{54}$.

$\mathrm{Bu}$ durumda ise tasarıda yer alan maddenin Komisyon raporundaki diğer gerekçe karşısındaki durumu tartı̧̧1abilir: "Anayasa Mahkemesi hem hakim hem savcl durumuna düşürülmemelidir... Ayhan Sefer Üstün bölümlerde görev yapan üyelerin genel kurula da katılacaklarını bunun, sakıncalı olduğunu... yasama organının kanundan kaynaklanan ihlallerde hassasiyet göstererek yeni düzenlemeyi yapması gerektiğini söylemiştir”. Komisyon raporuna göre, bir üyenin bireysel başvuruyu inceleyen Bölüm'de kanunun Anayasayı ihlal ettiği kanısına vardıktan sonra Genel Kurul'da aynı kanunun anayasaya aykırılığ 1 iddiasını incelemesi hâkim tarafsızlığına aykırı bir durum teşkil edecektir. Benzer şekilde, kanunun anayasaya aykırı olmadığını düşünen ve azınlıkta kalan bir üyenin de Genel Kurul'da yer alması hâkim tarafsızlığı açısından sakıncalı görülebilir. 6216 sayılı Kanun'un 59/1-ç maddesi, başkan ve üyelerin "hâkim, savcı, hakem sıfatıyla bakmış veya tanık ya da bilirkişi olarak beyanda bulunmuş olduğu dava ve işlere" bakamayacağını belirtmektedir. Bu hükmün maksadı Anayasa Mahkemesi üyesinin bir dava veya iş hakkında önceden edindiği kanaatlerin etkisini ortadan kaldırmaktır ${ }^{55}$. Bu durumda bireysel başvuruya bakan Bölüm'deki üyelerin, ihlal eden kanunun anayasaya aykırılığına ilişkin iptal davasına bakamayacağını söyleyebiliriz ${ }^{56}$. Hâl böyleyken, yani Anayasa Mahkemesi üyelerinin tarafsızlığına dair böyle bir hüküm mevcutken ve bu hüküm bireysel başvuru dışındaki durumlara uygulanabilirken, Komisyon raporundaki gerekçeye hak vermek mümkün müdür?

Komisyon'daki gerekçede belirtilmese de, mevcut hükümler 1şı̆̆ında bireysel başvuruya bakan üyelerin Genel Kurul önündeki iptal davasına bakamayacak olmasının şöyle bir pratik sakıncası olabilir: 6216 sayılı Kanun'un 22/1 maddesine göre, Bölümler bir başkanvekili ve dört üyenin katılımıyla, yani toplam beş üyeyle toplanır. Bir bölümde ise başkanvekili ile birlikte toplam altı üye bulunur ${ }^{57}$. Aynı kanunun 21/1 maddesine göreyse, Genel Kurul on beş üyeden oluşur ve en az on üye ile toplanır. Bu durumda, bireysel başvuru sırasında kanunun anayasaya

\footnotetext{
${ }^{53}$ Tahsin Erdinç de tasarıda yer alan hükmün çıkarılmasının isabetsiz olduğunu düşünmektedir (bkz. ERDİNÇ, s.113). Burada söylediklerimizin tasarıdaki hükmün çıkarılmasının niçin hukuken doğru olduğunu açıklayabildiğini umuyoruz. ${ }^{54}$ Alman hukuk sisteminde bir yasama işleminden kaynaklanan temel hak ve özgürlük ihlallerinin başka türlü çözülmesi mümkün değilse ve ihlal doğrudan bu işlemden kaynaklanır nitelikteyse, yasama işlemine karş1 anayasa şikâyeti (Verfassungsbeschwerde) gerçekleştirilebilmekte (bkz. EPPING, Volker: Grundrechte: In Zusammenarbeit mit Sebastian Lenz und Phillipp Leydecker, Springer, Berlin 2004, s.70; HARBICH, Jurgen: "Die Verfassungsbeschwerde zum Bundesverfassungsgericht", Studia Iuridica Auctoritate Universitatis Pecs Publicata, 135, 2005, s.39) ve bu başvurunun neticesinde Alman Federal Anayasa Mahkemesi yasama işlemini geçersiz kılabilmektedir (bkz. HARBICH, s.39). Macaristan örneğinde ise Anayasa Mahkemesi yalnızca hak ihlaline sebep olan soyut normu denetlemekte, somut durumdaki ihlale ilişkin bir karar vermemekte ve hak ihlaline yol açtığını tespit ettiği soyut normu geçersiz kılmaktadır (bkz. ZAKARIAS, Kinga: "Problematik des Verhaltnisses der Grundrechte zum Privatrecht im Ungarischen Recht", Iustum Aequum Salutare, 6(3), 2010, s.236-237; SÁRI, János: "Schutz und Garantien der Durchsetzung der Grundrechte im Ungarischen Verfassungssystem", Annales Universitatis Scientiarum Budapestinensis de Rolando Eotovos Nominatee: Sectio Iuridica, 43, 2002, s.8; PIEROTH, Bodo: "Das Verfassungsgericht als Kommunikatives Element Moderner Verfassungsstaatlichkeit, Rechtstheorie, 34(3), 2003, s.304). Avusturya'da ancak uygulama niteliğindeki nihaî idarî işlem üzerine bireysel başvuru yapılabilmektedir (HAMDEMİR, s.64). Bununla birlikte, temel hak ve özgürlük ihlali anayasaya aykırı bir kanundan kaynaklanıyorsa, anayasa mahkemesi bireysel başvuru ile birlikte kanunun anayasaya uygunluk denetimini başlatabilmektedir (bkz. HAMDEMIR, s.66).

55 ÖDEN, Merih: "Anayasa Yargısında Yargıcın Davaya veya İșe Bakamaması", Ankara Üniversitesi Hukuk Fakültesi Dergisi, 43 (1-4), 1993, s.78.

56 Tolga Şirin'e göre Anayasa Mahkemesi yüce divan sıfatıyla yaptığı yargılamalarda ve siyasi parti kapatma davalarında hem davayı çözerken uygulayacağı kanunun anayasaya aykırı olduğundan şüphelenip hem de söz konusu kanunun anayasaya uygunluk denetimini gerçekleştirebilmektedir. Dolayısıyla, yüce divan sıfatıyla yapılan yargılamalar ve siyasi parti kapatma davalarında bu husus kabul edilirken, bireysel başvuru açısından kabul edilmemesi için bir sebep yoktur. Bkz. ŞİRIN, Türkiye'de Anayasa Şikâyeti (Bireysel Başvuru): İnsan Hakları Avrupa Mahkemesi ve Almanya Uygulaması ile Mukayeseli Bir İnceleme, s.282.

${ }^{57}$ Bkz. GÖZLER, Türk Anayasa Hukuku, s.1081.
} 
aykırı olduğu kanısına varılan toplantıda altı üyenin bulunduğu durumlarda, bu üyelerin iptal davasına bakamayacağı ve dolayısıyla da toplantı için yeter sayıya erişilemeyeceği için iptal davasının görülemeyeceği mi düşünülmelidir? 6216 sayılı Kanun'un 60/3 maddesi her ne kadar "Genel Kurul ya da bölümlerin toplanmasına mani olacak sayıda üyenin reddine ilişkin talepler dinlenmez" dese de, söz konusu hüküm üyelerin davaya bakmaktan kesin yasaklı olduğu durumlara değil, tarafsızlıklarından kuşku edilebilecek olan durumlara ilişkindir. Bir üyenin bireysel başvuru neticesinde söz konusu kanununun anayasaya aykırılığı hakkında bildirdiği görüş ise 59. madde kapsamında yasaklılık hâlini örneklendirir.

Bireysel başvurunun 6 üyenin katılımıyla görüldüğü durumlarda söz konusu kanunun anayasaya aykırılı̆̆ına dair iptal davasının görülüp görülemeyeceği belirsizdir. 6216 sayılı Kanun'un 21/1 maddesi Genel Kurul'un 10 üye ile toplanacağını, 59/1-ç maddesi ise bireysel başvuruyu inceleyen 6 üyenin olası bir iptal davasına bakamayacağını düzenlemektedir. Ĕger tasarıdaki madde kanunlaşsaydı, ortaya çıkan durumun ideal bir durum olmayacağı açıktı. Bununla birlikte, söz konusu sorun anayasa değişikliği gerektirmeyen, kanunda yeniden düzenleme yapılmasıyla giderilebilecek, aşılabilecek bir sorundur. Dolayısıyla, Komisyon raporunda Anayasa Mahkemesinin üyelerinin tarafsızlığına ilişkin gerekçenin nihai bir geçerliliğe sahip olmadığını, üyelerin tarafsızlığını etkileyebilecek durumlara ilişkin önlemler kanunla alınmışken, bireysel başvuru neticesinde ilgili bölüm tarafından Genel Kurulda iptal davası açılmasının önüne geçilmesi için geçerli bir sebep olmadığını söyleyebiliriz.

Son olarak, Komisyon raporundaki gerekçe geçerli kabul edilirse, bireysel başvuruya bakan bölümde görev yapan üyeler bir kere belli bir kanunun temel hak ve hürriyetleri ihlal ettiğini tespit ettiğinde, sonradan söz konusu kanun diğer mahkemeler tarafından Genel Kurulun önüne taşınmış olsa dahi, Anayasa Mahkemesinin anayasaya uygunluk denetimini gerçekleştirmekten kaçınması gerekecektir. Nitekim Anayasa Mahkemesinin üyeleri değişmediği sürece, bu üyelerden bazıları anayasaya aykırılık iddiasını bireysel başvuru sırasında gündeme getirmiş olacaklardır. Kanımızca Komisyon raporunda açıklanan gerekçeyle bazı kanunlara anayasaya aykırı biçimde yargısal denetim bağışıklığı tanınması mümkün değildir. Dolayısıyla, gerekçenin geçersiz olduğunu kabul etmek gerekir.

\section{B. Yasama Organının Kanunu İlga Etmesi veya Yeniden Yargılama Yapan Mahkemenin Somut Norm Denetimine Gitmesi}

Kabul edilebilir bulunan bir bireysel başvuru neticesinde Anayasa Mahkemesi iki tür karar verebilir. Ya başvurucunun bir temel hak ve özgürlüğünün ihlal edildiğine karar verecek (ihlal kararı) ya da başvuruyu esastan reddedecektir. Bizi burada ilgilendiren Anayasa Mahkemesinin ihlal kararının içeriği, yani bu kararın ihlal tespitinden başka neleri içerdiği/içerebileceğidir.

İhlal kararı yalnızca bir tespitten ibaret değildir. 6216 sayılı Kanun'un 50/1 maddesine göre, Anayasa Mahkemesi ihlalin ve sonuçlarının ortadan kaldırılması için yapılması gerekenlere de karar verir. Aynı maddenin üçüncü fikrasında ihlalin mahkeme kararından kaynaklandığı durumlara ilişkin olarak şu hüküm yer almaktadır:

"Tespit edilen ihlal bir mahkeme kararından kaynaklanmışsa, ihlali ve sonuçlarını ortadan kaldırmak için yeniden yargılama yapmak üzere dosya ilgili mahkemeye gönderilir. Yeniden yargılama yapılmasında hukuki yarar bulunmayan hallerde başvurucu lehine tazminata hükmedilebilir veya genel mahkemelerde dava açılmast yolu gösterilebilir. Yeniden yargılama yapmakla yükümlü mahkeme, Anayasa Mahkemesinin ihlal kararında açıkladı̆̆ ihlali ve sonuçlarını ortadan kaldıracak sekilde mümkünse dosya üzerinden karar verir".

Şu durumda iki hâlde ihlale yol açan kanunun geçersiz kılınması mümkün olabilir: 1) Anayasa Mahkemesi kanunun temel hak ve özgürlükleri ihlal ettiğini tespit edip, yasama organından söz konusu kanunu ilgasını talep edecek veya 2) ihlale yol açan nihai işlemin bir mahkeme kararı olduğu durumlarda, yeniden yargılama yapılmasına gerek görülürse, yeniden yargılamayla yükümlü olan mahkeme ihlallerin ortadan kaldıracak şekilde karar vermekle yükümlü olduğu için, anayasaya aykırı kanun açısından somut norm denetimine gidecektir. Önce kanunun geçersiz kılınma ihtimallerinden ilkinin hukuka uygunluğunu denetleyelim.

1. İhlalin Ortadan Kaldırılması İçin Kanunun İlga Edilmesi Gerektiğinin Tespit Edilmesi

6216 sayılı Kanun'un 50/1 maddesine göre, "İhlal kararı verilmesi hâlinde ihlalin ve sonuçlarının ortadan kaldırılması için yapılması gerekenlere hükmedilir”. Ayrıca, Anayasanın 153/6 hükmüne göre, Anayasa Mahkemesi kararları yasama, yürütme ve yargı organlarını bağlar. Dolayısıyla, bir temel hak ve özgürlügün kanun tarafından ihlal edildiğinin tespiti hâlinde, Anayasa Mahkemesi ihlalin ortadan kaldırılması için söz konusu kanunun yasama organı tarafından 
yürürlükten kaldırması gerektiğine karar verebilir. Bu durumda söz konusu kararın yasama organı açısından bağlayıcı olacağı ve söz konusu kanunu yürürlükten kaldırmayan yasama organının (yasama organı üyelerinin) anayasayı ihlal etmiş olacağı düşünülebilir ${ }^{58}$.

Öncelikle, 6216 sayılı Kanun'un 45/3 hükmünün bu yoruma engel olup olmadığ değerlendirilmelidir. Söz konusu hüküm yasama işlemleri aleyhine doğrudan bireysel başvuru yapılmasının önüne geçmektedir. Buna göre, temel hak ve özgürlük bir kanun tarafından ihlal edilse dahi, bireysel başvuru yoluna gidilebilmesi için söz konusu kanunun bireysel idarî işlem veya mahkeme kararıyla uygulanması gerekir. Bir başka deyişle, araya bir uygulama işlemi girmeksizin kanundan kaynaklanan bir ihlalin bireysel başvuruya konu edilmesi mümkün değildir. Ancak, dikkat edilecek olursa, ilgili hüküm kanundan kaynaklanan ihlalin ortadan kaldırılması için yapılması gerekenlere hükmedilemeyeceğine değil, kanundan kaynaklı ihlaller açısından bir uygulama işlemi (bireysel idarî işlem veya mahkeme kararı) olmaksızın bireysel başvuru yapılamayacağına işaret etmektedir. Dolayısıyla, 6216 sayılı Kanun'un 45. maddesinin bireysel başvuru neticesinde ihlalin ortadan kaldırılması için ihlal eden kanunun ilga edilmesi gerektiğinin tespit edilmesine engel olamaz. Sonuç olarak, bireysel başvuru için olağan kanun yollarının tüketilmesi de gerektiğinden, ancak bir mahkeme süreci ve mahkeme kararını takiben bireysel başvuru gerçekleştirilebilecektir ${ }^{59}$. 6216 sayılı Kanun'un 45. maddesi ihlal kararı neticesinde ihlalin ortadan kaldırılmasıyla ilgili yasama organının yapması gerekene dair bir karar verilemeyeceğini ifade etmekten uzaktır.

Temel hak ve özgürlükleri ihlal eden bir kanun anayasaya aykırıdır. 1982 Anayasasına göre, anayasaya aykırı kanunların geçersiz kılınmasının usulü soyut veya somut norm denetiminden geçer. Anayasa Mahkemesinin bireysel başvuru neticesinde ihlalin ve sonuçlarının ortadan kaldırılması için yapılması gerekenlere de hükmedebileceği Anayasa tarafindan değil, 6216 sayılı Kanun tarafından öngörülmüş̧ür. Dolaysıyla, 6216 sayılı Kanun'un 50/1 maddesi ile anayasaya aykırı bir kanunun geçersiz kılınmasının önünün açıldığı, bunun ise anayasaya aykırı olduğu iddia edilebilir.

Dikkat edilecek olursa, iptal davasında Anayasa Mahkemesi anayasaya aykırı bulduğu kanunu doğrudan kendisi geçersiz kılmaktadır. Bu durumda, kanunla Anayasa Mahkemesinin ihlalin ortadan kaldırılması için ne yapılması gerektiğine karar vereceğinin öngörülmesi ve yasama organının belli bir kanunu ilga etmesi gerektiğine hükmetmenin bu yetkinin kapsamı içinde olması, Anayasanın soyut ve somut norm denetimine ilişkin hükümlerine aykırı olamaz. Bu hükümlerde söz konusu olan bir kanunun Anayasa Mahkemesi tarafından geçersiz kılınmasıdır. Tartışılan durum söz konusu kanunun Anayasa Mahkemesi kararıyla TBMM tarafindan geçersiz kılınmasıdır. Netice itibariyle, Anayasa Mahkemesi kararları bağlayıcı olduğuna (Anayasa m. 153/6) ve Anayasa Mahkemesi ihlal ile sonuçlarının ortadan kaldırılması konusunda karar vermeye yetkili olduğuna (6216 sayılı Kanun m. 50/1) göre, Anayasa Mahkemesinin belli bir kanunun temel hak ve özgürlükleri ihlal ettiği ve yasama organı tarafından ilga edilmesi gerektiği yönündeki kararının yasama organı açısından bağlayıcı olduğu hâlâ söylenebilir.

Anayasa Mahkemesinin temel hak ve özgürlükleri ihlal eden bir kanunun yasama organı tarafından kaldırılmasına karar verebilmesinin mahkemeyi negatif kanun koyucu olmaktan çıkarıp, pozitif kanun koyucu konumuna sokacağı da iddia edilebilir"60. Anayasa Mahkemesinin "negatif

\footnotetext{
${ }^{58}$ Bkz. AYDIN, s.141-142. Bu görüşe bir eleştiri olarak ihlale neden olan kanunun yürürlükten kaldırılması sırasında işaretle oylama yapılabilmesi nedeniyle ihlale hangi üyelerin yol açtığının belirlenmesinin güç olabileceği belirtilmektedir. Bu eksikliğin TBMM İçtüzüğünde ilgili oylamanın açık oy usulüyle yapılması gerektiği yönünde bir hüküm öngörerek giderilebileceği belirtilmektedir (bkz. HAMDEMİR, s.193). Bizim burada ilgilendiğimiz husus bireysel başvuruyu inceleyen bölümün yasama organına bir kanunun yürürlükten kaldırılması şeklinde talimat verme yetkisine - neticede bağlayıcı karar vermek ile talimat vermek arasında bunların ağırlığı, gücü vs. arasında fark bulunmamaktadır - sahip olup olmadığı ile sınırlıdır.

${ }^{59}$ Bunun tek istisnası olarak Anayasa Mahkemesinin etkili bir başvuru yolunun bulunmadığına karar verdiği ihlaller gösterilebilir. Anayasa Mahkemesine göre tüketilmesi gereken başvuru yolları bir sonuç vermesi mümkün olan, hak ihlalini ortadan kaldırması beklenebilecek olan yollardır (bkz. Anayasa Mahkemesinin 7 Kasım 2013 tarihli ve 2013/1582 başvuru numaralı Taner Kurban kararı, 23. paragraf, T.C. Anayasa Mahkemesi Kararlar Bilgi Bankas1, https://kararlarbilgibankasi.anayasa.gov.tr/BB/2013/1582?BasvuruNoYil=2013\&BasvuruNoSayi=1582, Erişim Tarihi: 27 Kasım 2020; Anayasa Mahkemesinin 7 Kasım 2013 tarihli ve 2013/2355 başvuru numaralı S.S.A. kararı, 28. paragraf, T.C. Anayasa Mahkemesi Kararlar Bilgi https://kararlarbilgibankasi.anayasa.gov.tr/BB/2013/2355?BasvuruNoYil=2013\&BasvuruNoSayi=2355, Erişim Tarihi: 27 Kasım 2020). Etkili başvuru yolunun bulunmadığ durumlarda bireysel başvuruya konu olan bir ihlale mahkeme kararının yol açmadığı, mahkeme kararının ihlalin oluşumunda rol oynamadığı söylenebilir.

${ }^{60} \mathrm{Bu}$ iddia Ergun Özbudun tarafından Anayasa Mahkemesi kararlarının yalnızca hüküm fıkrasının değil, gerekçelerinin de bağlayıcı olduğu yönündeki görüşü eleştirmek için ileri sürülmüştür. Bkz. ÖZBUDUN, Ergun: Türk Anayasa
} 
kanun koyucu" olarak adlandırılmasının nedeni mahkemenin kanunları geçersiz kılabilmesidir ${ }^{61}$. Bir başka deyişle, Anayasa Mahkemesi kanun yapamayacak olsa da bir kanunu geçersiz kılabilir. Olas1 itiraza göre, Anayasa Mahkemesinin temel hak ve özgürlükleri ihlal eden bir kanunun yasama organı tarafından ilga edilmesi yönünde bağlayıcı karar verebilmesi durumunda, bir kanun ancak başka bir kanun tarafından yürürlükten kaldırılabileceği için, Anayasa Mahkemesinin kararı hukuken bir kanun yapılmasını gerektirecek ve mahkeme pozitif kanun koyucu gücüne kavuşacaktır. Böylelikle, Anayasa Mahkemesi kendisine Anayasa ile verilmemiş, kuvvetler ayrılığı ilkesine aykırı bir güce kavuşacaktır.

Yukarıda yaptığımız açıklamaya benzer şekilde, burada da kanunun doğrudan Anayasa Mahkemesinin iradesiyle ortaya çıkmadığını, ilga eden kanunun ortaya çıkabilmesi için yasama organının bir işleminin gerektiğini vurgulamak gerekir. Negatif kanun koyucu sıfatı Anayasa Mahkemesinin başka bir organın aracılığına gerek duymaksızın bir kanunu geçersiz kılabilmesinden kaynaklanır. Oysa Anayasa Mahkemesi ilga eden kanuna kendi iradesiyle yol açamayacaktır. Burada Anayasa Mahkemesi pozitif kanun koyucu olmaktansa yasama organının hiyerarşik üstü gibi davranmaktadır. Kanımızca temel hak ve özgürlükleri ihlal eden kanunun ilga edilmesi gerektiğine karar vermekle ilgili sorun da burada yatmaktadır.

Organlar hiyerarşisinde yasama organının hiyerarşik üstü asli veya tali kurucu iktidardır ${ }^{62}$. Yasama organının belli bir düzenlemeyi yapması gerektiği yönünde bağlayıcı bir norm ancak kurucu iktidar tarafindan yaratılabilir. Elbette, kurucu iktidarın yarattı̆̆ 1 bir norm olan Anayasa tarafından öngörülmesi durumunda Anayasa Mahkemesinin bu yetkiye sahip olduğu kabul edilebilir. Örneğin, negatif kanun koyucu normal şartlar altında yasama organıdır. Bununla birlikte, Anayasa bu yetkiyi belli şartlara tabi olmak kaydıyla (yalnızca anayasaya aykırı bulunan kanunları geçersiz kılabilme) Anayasa Mahkemesine de vermiştir. İhlalin ve sonuçlarının ortadan kaldırılması için yapılması gerekenlere hükmetme yetkisi ise Anayasa tarafından değil, bir kanun tarafından verilmektedir. Anayasa Mahkemesinin ihlali veya sonuçları ortadan kaldırmak için yasama organını bağlayan, yasama organını belli bir işlem tesis etmek yönünde yükümlü kılan bir karar verebileceği Anayasa değil, 6216 sayılı Kanun tarafından öngörülmektedir. Anayasal organların yetkilerini dar yorumlanması ve şüphe durumunda anayasal organların yetkisiz olduğunu düşünmek gerektiği için, anayasal düzlemde Anayasa Mahkemesinin bir kanunun ilga edilmesine karar verme yetkisinin bulunmadığ 1 kabul edilmelidir. Bu yetkiyi veren kanunun ise anayasaya aykırı olduğunu düşünmek gerekecektir. Bu durumda 6216 sayılı Kanun'un 50/1 maddesini dar yorumlamak suretiyle anayasaya aykırılığın önüne geçilebilir. Bir başka deyişle, ihlalin ve sonuçlarının ortadan kaldırılması için neyin yapılması gerektiğine hükme yetkisinin yasama organının yapması gerekenlere hükmetme yetkisini kapsamadığı düşünülmelidir.

2. Yeniden Yargılama Yapan Mahkemenin Somut Norm Denetimine Başvurmas1

Daha önce belirttiğimiz gibi, bireysel başvurudan önce mutlaka bir mahkeme süreci bulunmak zorundadır. Bireysel başvurudan önce kanun yollarının tüketilmesi gerekeceği, yarg1 denetiminin dışında tutulmuş olan normlardan dolayı bireysel başvuru gerçekleştirilemey eceği ve genel nitelikli normlardan kaynaklı ihlallerden dolayı doğrudan bireysel başvuru yapılamayacağı için, pratikte bireysel başvurudan önce mutlaka bir mahkeme sürecinin bulunması gerekecektir. İhlale yol açan işlemi geçersiz kılmayan her mahkeme kararının da temel hak ve özgürlükleri ihlal ettiği düşünülebileceği için, esasen Türk bireysel başvuru sisteminde her ihlalin aynı zamanda bir mahkeme kararından kaynaklanacağ 1 söylenebilir. Elbette bunun tersi doğru değildir. Bir başka deyişle, yalnızca mahkeme kararından kaynaklanan ihlallerin bulunması mümkündür.

Bu açıklamadan yola çıkarak, her bireysel başvuruda gerekli görülmesi hâlinde yeniden yargılama yoluna başvurulabileceğini söyleyebiliriz. İhlalin ve sonuçlarının ortadan kaldırılması için yeniden yargılama yapan mahkemenin yapması gerekenlerse Anayasa Mahkemesi tarafından belirlenecektir. Bu durumda temel hak ve özgürlükleri ihlal eden kanun aleyhine somut norm denetimi gerçekleştirilmesi gerektiği Anayasa Mahkemesi tarafından karara bağlanabilir. Böylelikle, anayasaya aykırı normun denetimi Anayasa çerçevesi içinde kalınarak

Hukuku, 3. Baskı, Yetkin, Ankara 2019, s.412. Anayasa Mahkemesi kararlarında hüküm fikrasıyla birlikte gerekçelerin de bağlayıcı olduğu görüşü için bkz. TEZİÇ, Erdoğan: "Türkiye'de Siyasal Düşünce ve Örgütlenme Özgürlüğ̈̈”, Anayasa Yargısı Dergisi, 7, 1990, s.46; SAĞLAM, Fazıl: “Yetki ve İşlev Bağlamında Anayasa Mahkemesi'nin Yasama Yürütme ve Yargı ile İlişkisi”, Anayasa Yargısı Dergisi, 13,1996, s.57-58.

${ }^{61}$ KELSEN, Hans: General Theory of Law and State, 3. Baskı, çev. Anders Wedberg, Harvard University Press, Cambridge 1949, s.157.

${ }^{62}$ Organlar hiyerarşisi hakkında genel olarak bkz. GÖZLER, Kemal: Hukuka Giriş, 10. Baskı, Ekin, Bursa 2013, s.181 185 . 
gerçekleştirilebilir. Sonuç olarak, sol kulak sağ elle gösterilmek suretiyle de olsa ihlal eden kanunun geçersiz k1lınmasının pozitif hukuka uygun bir yolunun bulunduğunu kabul edebiliriz. $\mathrm{Bu}$ yol doktrinde de kabul edilmekte ${ }^{63}$, ancak usul ekonomisine aykırı bir yöntem olduğu için eleştirilmektedir ${ }^{64}$.

Kanımızca olası ilk çözüm hem anayasa aykırı hem de etkisiz olabilecek bir yoldur. Anayasa Mahkemesi kararına rağmen temel hak ve özgürlükleri ihlal eden kanunu ilga etmekten kaçınan bir yasama organına karşı ne yapılabileceği meçhuldür. Bununla birlikte, anayasaya uygun olduğuna karar verdiğimiz "yeniden yargılama sırasında somut norm denetimine başvurma" yolu da etkisiz olabilir. Neticede yeniden yargılama yapan mahkeme de yasama organı gibi somut norm denetimine gitme konusunda hukuka aykırı bir direnme yoluna gidebilir. Bu durumda konunun olağan kanun yolları içinde tekrar değerlendirilmesi veya somut norm denetimine gitmeyen mahkeme veya mahkemelerin bu kararı dolayısıyla yeniden bireysel başvuru yapılması mümkün olsa da bu tür olasılıklar hakkı ihlal edilen kişiler açısından yıldırıcı bir hâl alabilir. Sorunun hem temel hak ve özgürlükleri korumak hem de kanunların anayasaya uygunluk denetimini gerçekleştirmek olan Anayasa Mahkemesi içinde çözülmesi çok daha yerinde olacaktır.

\section{SONUÇ}

Temel hak ve özgürlüklere aykırı kanunların geçerliliğini koruması "çatışan normların varlığı" ve "ihlalin devamlılığı" açısından sorunlar yaratır. Dolayısıyla, bireysel başvuru neticesinde temel hak ve hürriyetleri ihlal edildiği tespit edilen kanunun geçerliliğinin sona erdirilebilmesi gerekir. Türk hukuk sisteminde ihlalin bir mahkeme kararından kaynaklandığı ve Anayasa Mahkemesinin yeniden yargılama yapılmasında hukuki yarar gördüğü durumlarda, usul ekonomisi açısından sorunlu bir biçimde, yeniden yargılama yapan mahkemenin somut norm denetimine gitme yükümlülüğ̈̈ dolayısıyla bu sorun aşlabilir. Ancak, bu yolun usul ekonomisi açısından sakıncalı, yıldırıcı ve etkisiz olabileceğini yukarıda vurguladık.

Kanımızca bu sorunun en makul çözümü anayasa değişikliğine gitmektir. Bu değişiklikle bireysel başvuruya bakmakta olan bölümün Genel Kurul'da iptal davası açabilmesi sağlanmalıdır. Bölümde görev alan üyelerin Genel Kurul'a da katılmasının hukuk sistemi açısından yaratacağ sorun, temel hak ve özgürlükleri ihlal eden kanunların geçerliliğini korumasının yaratacağ sorundan çok daha önemsizdir. Kaldı ki bu şekilde açılan iptal davalarında bölümde görev alan üyelerin Genel Kurul'a katılamayacağı öngörülmek suretiyle bu sorunun da önüne geçilebilir. Eğer Türk bireysel başvuru sistemi yalnızca geçerli kanunları ihlal eden kişilerin hakkını korumayı amaçlayan ve ihlale sebep olan kanun geçerliliğini koruduğu için bu amaçta dahi başarılı olamayan, anayasaya aykırı kanunların geçersiz kılınmasında yasama organının iyi niyetinden fazlasına güvenen, etkili bir sistem olmayı amaçlıyorsa anayasal bir değiş̧iklik zorunlu görünüyor.

\footnotetext{
${ }^{63}$ AYDIN, s.141; HAMDEMİR, s. 192.

${ }^{64}$ ŞAHBAZ, s.91-94. 


\section{KAYNAKÇA}

ALIEFENDİŎLU, Yılmaz: Anayasa Yargısı ve Türk Anayasa Mahkemesi, Yetkin Ankara 1996.

ARMAĞAN, Servet: Anayasa Mahkemesinde Kazaî Murakebe Sistemi, İÜHF Yayınları, İstanbul 1967.

ATASOY, Hakan: "Bireysel Başvuruda Güncel Sorunlar", in Türkiye'de Anayasa Mahkemesine Bireysel Başvuru (Anayasa Şikayeti), ed. Sevtap Yokuş, 2. Baskı, Seçkin, Ankara 2015, s.227272.

AUSTIN, John: The Province of Jurisprudence Determined, ed. Wilfrid Ed. Rumble, Cambridge University Press, Cambridge 2001.

AYDIN, Öykü Didem: “Türk Anayasa Yargısında Yeni Bir Mekanizma: Anayasa Mahkemesi’ne Bireysel Başvuru", Gazi Üniversitesi Hukuk Fakültesi Dergisi, 15(4), 2011, s.121-170.

BULYGIN, Eugenio: "Norms, Normative Propositions, and Legal Statements", in FLØISTAD, G: Philosophy of Action: Contemporary Philosophy (A New Survey), Cilt: 3, Martinus Nijhoff, Lahey 1982, s.127-152.

EPPING, Volker: Grundrechte: In Zusammenarbeit mit Sebastian Lenz und Phillipp Leydecker, Springer, Berlin 2004.

ERDINÇ, Tahsin: "Karşılaştırmalı Olarak Türk Anayasa Mahkemesine Bireysel Başvuru Hakkı (Anayasa Şikâyeti)", Türkiye Adalet Akademisi Dergisi, 6(20), 2015, s.87-138.

GÖZLER, Kemal: Hukuka Giriş, 10. Bask1, Ekin, Bursa 2013.

GÖZLER, Kemal: Türk Anayasa Hukuku, 2. Bask1, Ekin, Bursa 2018.

GÖZLER Kemal: "Yorum İlkeleri”, in Anayasa Hukukunda Yorum ve Norm Somutlaştırması, ed. Ozan Ergül, Kamu Hukukçuları Platformu-Türkiye Barolar Birliği Ortak Yayını, Ankara 2013, s.15-119.

GÖZTEPE, Ece: “Ece Göztepe'nin Konuşması”, in Anayasa Mahkemesine Bireysel Başvuru: Anayasa Şikayeti/Anlamı ve Olası Sorunlar, TBB Yayını, Ankara 2011, s.32-43.

GÖZTEPE, Ece: “Türkiye'de Anayasa Mahkemesi’ne Bireysel Başvuru Hakkının (Anayasa Şikâyeti) 6216 Sayılı Kanun Kapsamında Değerlendirilmesi”, Türkiye Barolar Birliği Dergisi, 95, 2011, s.13-40.

GÜLGEÇ, Yahya Berkol: Lex Superior İlkesi: Hukuki Geçerliliği ve Uygulaması, On İki Levha, İstanbul 2018.

GÜLMEZ, Mesut: ““Örgütlenme Özgürsüzlüğ̈̈’ Cephesinde Yeni Bir Şey Yok! Olacağı da Yok”, Çalışma ve Toplum, 2, 2013, s.13-40.

HAMDEMİR, Berkan: Anayasa Mahkemesine Bireysel Başvuru, 2. Baskı, Seçkin, Ankara 2018.

HARBICH, Jürgen: "Die Verfassungsbeschwerde zum Bundesverfassungsgericht", Studia Iuridica Auctoritate Universitatis Pecs Publicata, 135, 2005, s.32-48.

HOBBES, Thomas: Leviathan, çev. Semih Lim, Yapı Kredi Yayınları, İstanbul 2013.

İNCEOĞLU, Sibel: Anayasa Mahkemesi'ne Bireysel Başvuru: Türkiye ve Latin Modelleri, On İki Levha, İstanbul 2017.

KARAMAN, Ebru: Karşılaştırmalı Anayasa Yargısında Bireysel Başvuru Yolu, On İki Levha, İstanbul 2013.

KELSEN, Hans: General Theory of Law and State, çev. Anders Wedberg, 3. Baskı, Harvard University Press, Cambridge 1949.

KELSEN, Hans: General Theory of Norms, çev. Michael Hartney, Clarendon Press, Oxford 1991.

KILINÇ, Bahadır: "Karşılaştırmalı Anayasa Yargısında Bireysel Başvuru (Anayasa Şikâyeti) Kurumu ve Türkiye Açısından Uygulanabilirliği”, Anayasa Yargısı, 25, 2008, s.19-59.

KRAMER, Matthew H.: "Freedom and the Rule of Law", Alabama Law Review, 61 (4), 2010, s.827-845.

KRAMER, Matthew H.: "On the Counterfactual Dimension of Negative Liberty", Politics, Philosophy \& Economics, 2 (1), 2003, s.63-92.

KRAMER, Matthew H.: The Quality of Freedom, Oxford University Press, Oxford 2003.

ÖDEN, Merih: “Anayasa Yargısında Yargıcın Davaya veya İşe Bakamaması”, Ankara Üniversitesi Hukuk Fakültesi Dergisi, 43 (1-4), 1993, s.61-124.

ÖZBUDUN, Ergun: Türk Anayasa Hukuku, 3. Baskı, Yetkin, Ankara 2019.

PIEROTH, Bodo: "Das Verfassungsgericht als Kommunikatives Element Moderner Verfassungsstaatlichkeit”, Rechtstheorie, 34(3), 2003, s.299-305.

SAĞLAM, Fazıl: “Anayasa Şikâyetini Bekleyen Sorunlar”, in Anayasa Mahkemesine Bireysel Başvuru: Anayasa Şikayeti/Anlamı ve Olası Sorunlar, TBB Yayını, Ankara 2011, s.20-31.

SAĞLAM, Fazıl: "Yetki ve İşlev Bağlamında Anayasa Mahkemesi’nin Yasama Yürütme ve Yargı ile İlişkisi”, Anayasa Dergisi, 13, 1996, s.43-60.

SÁRI, János: "Schutz und Garantien der Durchsetzung der Grundrechte im Ungarischen Verfassungssystem", Annales Universitatis Scientiarum Budapestinensis de Rolando Eotovos Nominatee: Sectio Iuridica, 43, 2002, s.5-19.

SİLIER, Yıldız: “İki Özgürlük Anlayışı”, Felsefe Tartışmaları, 31, 2003, s.51-68.

SKINNER, Quentin: "The Idea of Negative Liberty: Philosophical and Historical Perspectives", in RORTY, Richard/SCHNEEWIND, Jerome B./SKINNER, Quentin: Philosophy in History: 
Essays on the Historiography of Philosophy, Cambridge University Press, Cambridge 1984, s.193-221.

ŞAHBAZ, İbrahim: “Anayasa Mahkemesine Bireysel Başvuru ve Sorunlar”, in Anayasa Mahkemesine Bireysel Başvuru: Anayasa Şikayeti/Anlamı ve Olası Sorunlar, TBB Yayını, Ankara 2011, s.71-128.

ŞİMŞEK, Tacettin: “İdari Yargı Açısından Anayasa Mahkemesine Bireysel Başvuru Hakkı”, in Anayasa Mahkemesine Bireysel Başvuru: Anayasa Şikayeti/Anlamı ve Olası Sorunlar, TBB Yayın1, Ankara 2011, s.129-141.

ŞİRIN, Tolga: Anayasa Mahkemesi Kararları Işı̆̆ında Bireysel Başvuru Hakkı, On İki Levha, İstanbul 2015. ŞİRIN, Tolga: Türkiye'de Anayasa Şikâyeti (Bireysel Başvuru): İnsan Hakları Avrupa Mahkemesi ve Almanya Uygulaması ile Mukayeseli Bir İnceleme, On İki Levha, İstanbul 2013.

TEZİÇ, Erdoğan: “Türkiye’de Siyasal Düşünce ve Örgütlenme Özgürlüğü”, Anayasa Yargısı Dergisi, 7, 1990, s.31-46.

ZAKARIAS, Kinga: "Problematik des Verhaltnisses der Grundrechte zum Privatrecht im Ungarischen Recht”, Iustum Aequum Salutare, 6(3), 2010, s.227-244. 